UNIVERSIDADE DE BRASÍLIA

CENTRO DE DESENVOLVIMENTO SUSTENTÁVEL

\title{
A MEDIAÇÃO COMO MECANISMO DE RESOLUÇÃO DE CONFLITOS SOCIOAMBIENTAIS
}

\author{
Claudia Vechi Torres
}

Orientadora: Francisca Neta Andrade Assunção

Monografia do Curso de Especialização em Desenvolvimento Sustentável e Direito Ambiental

Brasília-DF: 05/2006 
UNIVERSIDADE DE BRASÍLIA

CENTRO DE DESENVOLVIMENTO SUSTENTÁVEL

\title{
A MEDIAÇÃO COMO MECANISMO DE RESOLUÇÃO DE CONFLITOS SOCIOAMBIENTAIS
}

\author{
Claudia Vechi Torres
}

Monografia submetida ao Centro de Desenvolvimento Sustentável da Universidade de Brasília, como parte dos requisitos necessários para a conclusão do Curso de Especialização em Desenvolvimento Sustentável e Direito Ambiental.

Aprovado por:

Francisca Neta Andrade Assunção

Magda Eva Soares de Faria Wehrmann

Vanessa Maria de Castro

Brasília-DF, 22 de maio de 2006 
TORRES, CLAUDIA VECHI

A Mediação como Mecanismo de Resolução de Conflitos SocioAmbientais.

Monografia - Universidade de Brasília. Centro de Desenvolvimento Sustentável.

1. Conflito Socioambiental 2. Mediação

I. UnB-CDS II. Título (série)

É concedida à Universidade de Brasília permissão para reproduzir cópias desta monografia e emprestar ou vender tais cópias somente para propósitos acadêmicos e científicos. O autor reserva outros direitos de publicação e nenhuma parte desta monografia pode ser reproduzida sem a autorização por escrito do autor. 


\section{DEDICATÓRIA}

Dedico este trabalho a Deus, fonte do amor e de sabedoria, luz na minha caminhada terrena, força nos momentos difíceis e esperança num amanhã mais justo e fraterno.

A meus pais e irmã, minha primeira família, responsáveis pela minha determinação em buscar a paz por meio do diálogo e da não-violência.

Ao meu marido, grande amigo e companheiro, sempre presente em todos os momentos de minha vida, meu porto seguro no mar de tribulações, meu bálsamo benigno.

Aos meus filhos, Arthur, André e Anne, fontes de alegria, motor que me coloca em movimento contínuo em busca de um mundo mais justo.

conhecimento.

Aos meus amigos, que sempre me incentivaram a caminhar na busca pelo

Aos promotores da paz, semeadores do amor mútuo no mundo. 


\section{AGRADECIMENTOS}

Agradeço a todos que cooperaram para a confecção desta monografia, e em particular aos professores Fernando Scardua, Francisca Neta e Vanessa Castro que indicaram bibliografias, debateram o tema e disponibilizaram textos.

Em especial quero homenagear a professora Francisca Neta pela sua atenção, disponibilidade e cuidado na orientação desse tema.

Aos colegas do Curso de Especialização pelo convívio, amizade e apoio em todos os momentos do curso, em especial às colegas Sandra Marize e Priscila Bastos.

Aos professores e funcionários do Centro de Desenvolvimento Sustentável, pelos ensinamentos e convívio. 


\section{RESUMO}

A sociedade contemporânea vive grandes transformações que afetam todas as áreas da vida, em especial o meio ambiente. Essas transformações têm ensejado conflitos que normalmente são resolvidos por um juiz, via jurisdição estatal, não envolvendo as partes na solução dos problemas; principalmente quando se trata de conflitos coletivos que envolvem direitos difusos, como é o caso dos conflitos socioambientais. Dentre os diversos tipos de conflitos, o conflito socioambiental, conta com características peculiares, envolvendo múltiplos atores e grupos sociais, que enfrentam inúmeras dificuldades ao procurarem a via judicial para solucionarem questões ambientais. Há a necessidade do diálogo, da participação, da cooperação e da solidariedade dos diversos segmentos da sociedade na busca de uma solução pacífica e consensual que viabilize a melhora da qualidade de vida e a sustentabilidade ambiental. Desta maneira, a mediação é apresentada como mecanismo alternativo de resolução de conflitos, especialmente dos conflitos socioambientais, por ser uma técnica que transcende os propósitos imediatos da resolução de conflitos e da pacificação social, visto que atende aos apelos da compreensão mútua, da comunicação e da dignidade humana. A base da mediação é a comunicação, o diálogo mediado por um terceiro, que possibilita a construção da solução pelas partes envolvidas no conflito. A mediação exterioriza a visão construtiva do conflito, educando as partes durante a administração do conflito e construindo a paz social. A institucionalização da mediação na gestão ambiental brasileira é o discurso recentemente apresentado pela ministra do Meio Ambiente e analisado neste trabalho, como ferramenta capaz de alcançar soluções consensuais nos conflitos socioambientais manifestados não somente no processo de licenciamento ambiental, mas em todos os conflitos que envolvam o uso e aproveitamento dos recursos naturais. A criação de Câmaras de Mediação, apesar de não encontrarem atualmente respaldo legal, proporcionariam, dentre outros aspectos, a participação da sociedade, a inclusão social, a defesa e proteção do meio ambiente. 


\begin{abstract}
Contemporary society lives a great transformation that affect all areas of life, especially the environment. These transformations have caused conflicts that normally are decided by a judge, through the state jurisdiction and not involving people; mainly when it deals with collective conflicts that involve diffuse rights, for example, environmental conflicts. Amongst the diverse types of conflicts, the environmental conflict appears, with peculiar characteristics, such as multiple actors and social groups that face innumerable difficulties when looking for a judicial way to solve environment questions. There is a great necessity of dialogue, participation, cooperation and solidarity of the diverse segments of the society in the search of a pacific and consensual solution that makes possible the improvement of the quality of life and the sustentability. The mediation is presented as an alternative mechanism of conflict resolution, especially in the case of environmental conflicts, being a technique that exceeds the immediate intentions of the conflict resolution and the social pacification, since it takes care of the call of mutual understanding, communication and human dignity. The base of mediation is communication, dialogue mediated for a third, a person that makes possible the construction of a solution for the involved parts in the conflict. Mediation presents a constructive vision of the conflict, educating the parts during the administration of it, also constructing social peace. The institutionalization of the mediation in Brazil is part of the speech recently presented by the Minister of the Environment and it is analyzed here in this work, as a tool able not only to reach consensual solutions in the revealed environmental conflicts in the process of environmental licensing, but in all conflicts that involve the use and exploitation of natural resources. The creation of Chambers of Mediation, although has not found legal endorsement, would provide participation of the society, the social inclusion, the defense and protection of the environment.
\end{abstract}




\section{SUMÁRIO}

LISTA DE FIGURAS

LISTA DE ABREVIATURAS E SIGLAS

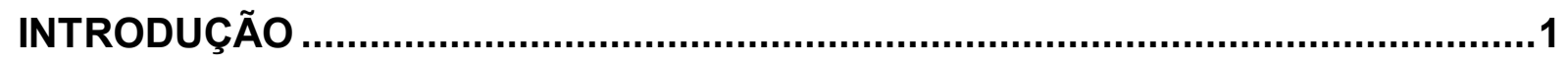

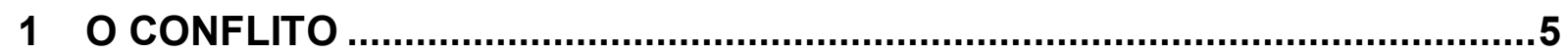

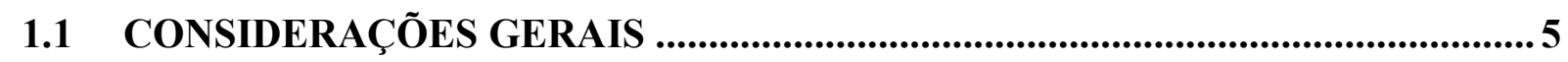

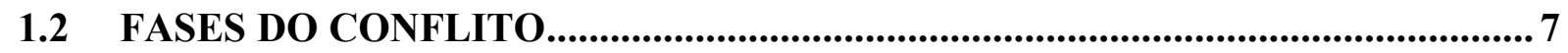

1.3 TIPOLOGIA DO CONFLITO

1.4 ADMINISTRAÇÃO E RESOLUÇÃO DO CONFLITO ...................................... 12

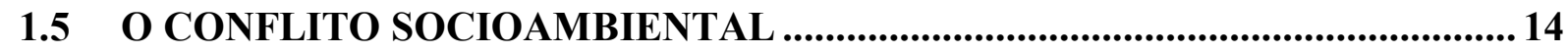

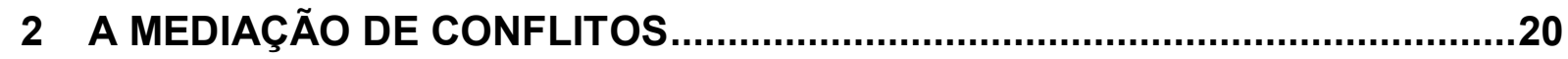

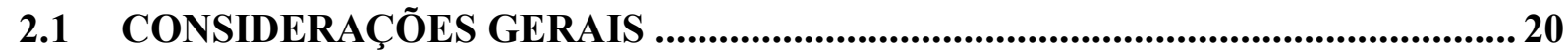

2.2 CONCEITOS, OBJETIVOS E ELEMENTOS DA MEDIAÇÃO........................... 22

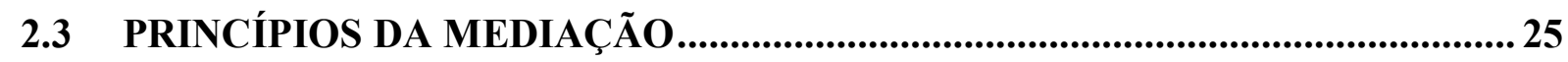

2.4 MEDIAÇÃO: VANTAGENS, DESVANTAGENS, EFICÁCIA E LIMITES ....... 27

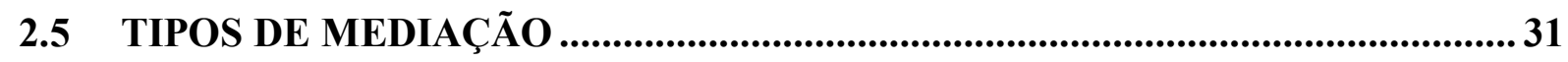

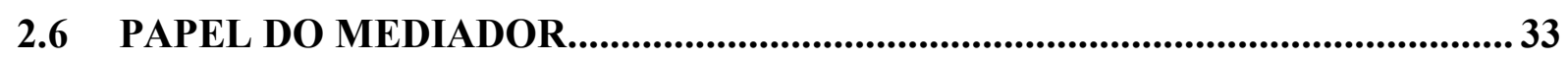

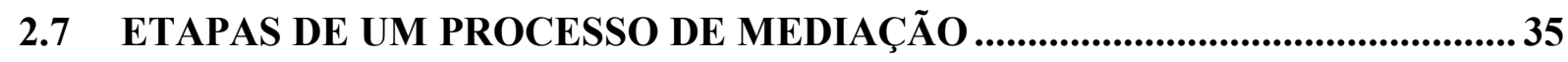

3 A MEDIAÇÃO NA RESOLUÇÃO DOS CONFLITOS SOCIOAMBIENTAIS ......40

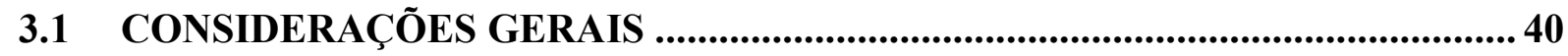

3.2 A MEDIAÇÃO NA CONSTITUIÇÃO BRASILEIRA .........................................42

3.3 O MEIO AMBIENTE NA CONSTITUIÇÃO BRASILEIRA..............................44 
3.4 A GESTÃO AMBIENTAL BRASILEIRA: PRINCÍPIOS E INSTRUMENTOS. 45 3.5 O ANTEPROJETO QUE INSTITUCIONALIZA A MEDIAÇÃO NO

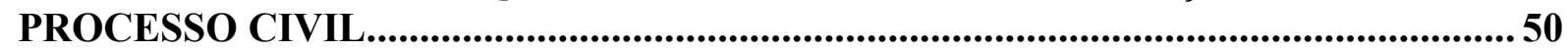

3.6 A INSTITUCIONALIZAÇÃO DA MEDIAÇÃO PARA RESOLUÇÃO DE CONFLITOS SOCIOAMBIENTAIS...........................................................................52

4 CASOS DE MEDIAÇÃO DE CONFLITOS SOCIOAMBIENTAIS .......................57

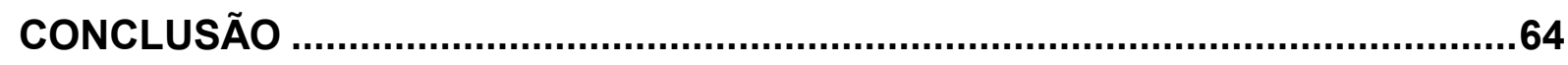

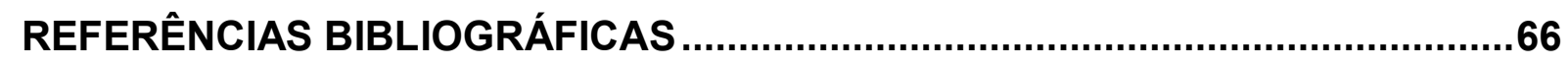

ANEXO A

ANEXO B 


\section{LISTA DE FIGURAS}

FIGURA 1 - Tipos de Mediação 


\section{LISTA DE ABREVIATURAS E SIGLAS}

ADR - Alternative Dispute Resolutions

AGU - Advocacia Geral da União

ANA - Agência Nacional de Águas

APA - Área de Proteção Ambiental

CONAMA - Conselho Nacional de Meio Ambiente

DRT - Delegacia Regional do Trabalho

IBAMA - Instituto Brasileiro de Meio Ambiente

INCRA - Instituto Nacional de Colonização e Reforma Agrária

MMA - Ministério do Meio Ambiente

MST - Movimento dos Sem-Terra

PA - Projeto de Assentamento

PNMA - Política Nacional de Meio Ambiente

OAB/DF - Ordem dos Advogados do Brasil/ Distrito Federal

ONG - Organização Não Governamental

RAD - Resolução Alternativa de Disputas

SISNAMA - Sistema Nacional de Meio Ambiente

TJDFT - Tribunal de Justiça do Distrito Federal e Territórios

UnB - Universidade de Brasília

UniCeub - Centro Universitário de Brasília

USAID - United States Agency for International Development 


\section{INTRODUÇÃO}

A sociedade contemporânea passa por uma crise de paradigmas decorrentes, dentre outros fatores, do capitalismo, da globalização, da crescente exclusão social, do surgimento de novas tecnologias e do conflito entre o homem e o meio ambiente.

Vivemos sob o domínio do modelo capitalista de produção, baseado na busca de melhores meios de competitividade, no aproveitamento de mão-de-obra barata e na exploração crescente dos recursos ambientais, com pouca preocupação com a preservação dos recursos naturais utilizados (ROCHA, 2006).

Nesse modelo de desenvolvimento capitalista, os recursos naturais são explorados de forma predatória, resultando na escassez, risco de escassez, extinção de espécies da flora e da fauna, além de comprometer o uso desses recursos no futuro. Ademais as novas tecnologias não minimizaram os resíduos gerados nos processos produtivos e no consumo e descarte de embalagens.

Os conflitos socioambientais surgem em função do comprometimento da qualidade de vida, das situações de escassez, da forma com que são utilizados os recursos naturais e do acesso injusto a esses recursos. Eles envolvem "disputas de natureza socioeconômica e o meio ambiente" (THEODORO, 2005:13).

$\mathrm{Na}$ solução da maioria desses conflitos têm sido utilizada a forma tradicional conhecida como jurisdição. No entanto, existe uma outra forma: a mediação, um mecanismo alternativo de resolução de disputas que possibilita o diálogo e o entendimento entre as partes, mediado por um terceiro imparcial e neutro.

A mediação, como método de solução consensual de conflitos, é um tema de relevância atual, que é objeto dos Projetos de Lei no 4.827/98 e 4.891/2005 em tramitação no Congresso Nacional e de um Anteprojeto que objetiva instituí-la no processo civil. 
A mediação não é completamente estranha ao ordenamento jurídico brasileiro. Na área trabalhista encontramos leis, decretos e portarias do Ministério do Trabalho e Emprego que disciplinam o seu uso, como a Lei $\mathrm{n}^{\mathrm{o}} 10.101 / 00$ e $\mathrm{n}^{\mathrm{o}} 10.192 / 01$ (MANUAL DO MEDIADOR, 2001).

Estatísticas comprovam a eficácia da mediação na área trabalhista, pois no ano de 2001 foram realizadas 9.498 medições coletivas em todo o território brasileiro, e até abril de 2002 foram realizadas 3.088 mediações coletivas ${ }^{1}$.

No campo extrajudicial, encontramos no Brasil projetos como o da Justiça Comunitária, desenvolvido pelo Tribunal de Justiça do Distrito Federal e Territórios (TJDFT) em parceria com a Universidade de Brasília (UnB), o Ministério Público, a Ordem dos Advogados do Brasil/Distrito Federal (OAB/DF) e a Defensoria Pública, objetivando construir junto a comunidade da Ceilândia meios de promoção de uma Justiça preventiva.

O projeto disponibiliza naquela comunidade um mediador capaz de resgatar os valores e a comunicação afetiva na busca da solução de conflitos. Esse mediador é capacitado pela Escola de Justiça e Cidadania do Distrito Federal, situada no Fórum da Ceilândia. Importa salientar que, isso não descartar o caminho jurisdicional prestado pelos Juizados Especiais, na figura do conciliador. (PROJETO JUSTIÇA COMUNITÁRIA, 2000).

No âmbito da gestão ambiental, a mediação poderá ser utilizada para viabilizar a solução de problemas e conflitos de interesse quanto ao uso e a proteção dos recursos ambientais. Também poderá ser usada para promover a participação social e melhorar a eficácia do processo de avaliação de impacto ambiental, quando existem interesses antagônicos entre os grupos sociais afetados pelo projeto e seu proponente.

Ressalta-se que a necessidade de institucionalizar a mediação de conflitos socioambientais foi reconhecida pela ministra do Meio Ambiente Marina Silva, em entrevista concedida à Folha de São Paulo no dia 19 de dezembro de 2003. No seu discurso, a Ministra mencionou a possibilidade de criação de Câmaras de Mediação em Conflitos Ambientais no Brasil, junto a Advocacia Geral da União, para tratar de conflitos relativos ao Licenciamento Ambiental (SATO, 2005).

\footnotetext{
${ }^{1}$ Fonte: DRT's
} 
$\mathrm{Na}$ entrevista, a ministra demonstra que pretende institucionalizar um espaço de mediação de conflitos socioambientais, via a criação de Câmara de Mediação, para que as partes envolvidas no conflito tenham a oportunidade de avaliar, administrar e resolver de forma consensual a questão ambiental objeto da crise.

Este trabalho tem como objetivo analisar se é viável utilizar a mediação na resolução de conflitos socioambientais, com base no referencial teórico sobre o tema e nas ferramentas legais disponíveis. Para tanto, procurou-se entender o que é o conflito socioambiental, o que é a mediação e a possibilidade de utilizá-la como instrumento capaz de viabilizar a avaliação, a administração e a resolução de conflitos sociambientais.

Para atender o objetivo desta monografia formulou-se as seguintes questões orientadoras:

- Quais são as característica dos conflitos socioambientais?

- O que é mediação, qual a sua finalidade, os seus elementos, princípios e processo?

- A mediação pode ser utilizada no Brasil como mecanismo de resolução consensual de conflitos ambientais no âmbito extrajudicial, uma vez que a questão ambiental está inserida no rol dos direitos fundamentais?

- A mediação cabe como instrumento de resolução de conflitos socioambientais somente no licenciamento ambiental? O Advogado-Geral da União pode exercer a função de mediador?

A metodologia utilizada neste trabalho incluiu pesquisa bibliográfica, junto à Universidade de Brasília - UnB e o Centro Universitário de Brasília - UniCeub, atentandose, inicialmente, para verificar a existência de teses, dissertações e monografias que tratavam da problemática dos conflitos, e que focassem particularmente, os conflitos socioambientais e os meios utilizados para suas resoluções. Também foi efetuada pesquisa em livros e artigos de acervos dessas universidades e próprio; e, ainda, outros disponibilizados na rede mundial de computadores, com a finalidade de verificar a existência de normas legais sobre o assunto, e estudar autores que trabalharam com tais temas, e que enfatizassem os diversos conceitos e tipos de conflitos e mediação. 
O trabalho aqui apresentado está estruturado em quatro capítulos. No primeiro buscou-se dar ao leitor noções sobre conflito e conflito socioambiental. No segundo capítulo analisou-se as questões teóricas relativas a mediação, como: conceitos, objetivos, elementos, princípios, aspectos da mediação, papel do mediador e as etapas de um processo de mediação.

No terceiro capítulo analisou-se a possibilidade de institucionalização da mediação de conflitos socioambientais, a partir dos instrumentos legais disponíveis. Para isso, foi preciso verificar a viabilidade da mediação nas normas constitucionais, na legislação ambiental, particularmente na Política Nacional do Meio Ambiente. Também, procurou-se averiguar a viabilidade de implantação de Câmaras de Mediação Ambiental e a possibilidade do Advogado-Geral da União atuar como mediador do processo.

No último capítulo, buscou-se ilustrar a mediação, relatando três experiências de mediação de conflitos socioambientais. Essas experiências de mediação são empíricas e não seguem o aporte teórico mencionado no corpo do presente trabalho, no entanto servem para apoiar a iniciativa da ministra na criação das câmaras de mediação ambiental. 


\section{O CONFLITO}

Antes de iniciar o estudo da mediação e analisar a possibilidade de sua institucionalização como forma alternativa de resolução dos conflitos socioambientais conflitos estes que envolvem inúmeras disputas de natureza social, econômica e ambiental -, faz-se necessário o estudo do conflito. Desse modo, explorou-se os conceitos, fases e tipologia, para em seguida caracterizar-se o conflito socioambiental.

Analisar a distinção do conflito com relação à disputa e ao litígio, é a etapa preliminar necessária para se trabalhar a possibilidade de alcançar soluções pacíficas dos conflitos socioambientais, utilizando-se a mediação como uma ferramenta institucionalizada, capaz de promover a resolução consensual entre as partes.

\subsection{CONSIDERAÇÕES GERAIS}

A palavra conflito é usualmente utilizada para se referir a choque, embate entre pessoas, desavença, discussão, discórdia, oposição, luta, combate, guerra. Assim sendo, o conflito carrega em si uma conotação negativa, algo indesejável, que deve ser evitado, sendo o oposto da paz, tão almejada pela sociedade.

O conflito é alvo de estudo de diversas ciências e técnicas do conhecimento humano, tais como: (i) técnicas militares: que se baseiam em conflitos reais e potenciais; (ii) comércio internacional: que se baseia em interesses confrontados, que podem gerar conflitos e ditar regras entre mercados; (iii) sociologia: que estuda os conflitos sociais (SILVA, 2004).

Historicamente o conflito e os mecanismos utilizados na obtenção e sua resolução sofreram inúmeras alterações desde a sociedade primitiva até a sociedade moderna. Na sociedade primitiva ou não havia mecanismos de resolução de conflitos ou se havia, eram frágeis, isso tanto para conflitos internos como para externos. Na sociedade de coleta os conflitos eram resolvidos pela força ou cissipação. Na Antiguidade houve um maior desenvolvimento dos mecanismos de resolução de conflitos, ganhando força as noções de direito, de justiça e de mediação. Entretanto, os conflitos na Antiguidade eram normalmente 
externos, com outros povos, sendo a força o principal instrumento utilizado. Mesmo no Renascimento e nas sociedades coloniais a força continuou a ser o principal mecanismo de resolução de conflitos. (NASCIMENTO, 2001).

Com o surgimento da sociedade moderna (séculos XVIII e XIX) a noção de conflito é renovada, criam-se mecanismos de solução de conflitos mais eficientes, sem o uso da submissão ou da separação, mas que não dispensavam totalmente a força (NASCIMENTO, 2001).

Vários autores modernos estudaram o conflito, conceituando-o, identificando fases e criando tipologias, dentre eles destacam-se: Morton, Boulding e Rummel.

Morton (Apud SILVA, 2004:86) conceituou o conflito da seguinte forma:

duas individualidades confundidas pelas próprias limitações intrapsíquicas, se enfrentam por posições incompatíveis, determinadas pelo desejo de poder mais que o outro, estruturadas numa posição defensiva, cheia de preconceitos, que confunde mais do que esclarece os próprios interesses.

Para Boulding (Apud VEZZULLA, 1998:22) o conflito é uma "situação de concorrência, onde as partes estão conscientes da incompatibilidade de futuras posições potenciais, e na qual cada uma delas deseja ocupar uma posição incompatível com o desejo da outra”.

Rummel (Apud SERPA, 1999:25), por sua vez, conceitua o conflito como “o equilíbrio dos vetores de poder", pois nenhum dos atores tem poder suficiente para eliminar o conflito. Na realidade o conflito ocorre sempre que atividades incompatíveis entre pessoas, grupos ou nações, oriundas ou não da vontade, existem. Assim, o conflito é visto como "um processo dinâmico de interação humana e confronto de poder onde uma parte influencia e qualifica o movimento da outra".

Analisando os conceitos acima verifica-se que o conflito ocorre entre diferentes agentes, com posições, argumentos, interesses, desejos incompatíveis. Há oposição, confronto entre esses diferentes agentes, gerando um estado de tensão. Essa tensão poderá vir a ser administrada e resolvida de diversas formas. 
Apesar de muitas vezes a sociedade moderna apontar o conflito como algo indesejável, este não pode ser evitado uma vez que "é parte integral do comportamento humano" (SERPA, 1999:32), é “instrumento de mudanças" como afirma Morton (Apud SERPA, 1999:31). O conflito é um fator de evolução quando administrado e encarado como parte da dinâmica natural humana, é a forma de se avaliar capacidades e possibilidades, revelar diferenças, estimular o autoconhecimento e revitalizar normas.

O conflito pode não ser identificado por terceiros, nem ter efeitos aparentes, mas a partir do momento em que os agentes demonstram suas incompatibilidades a outrem, o conflito se transforma em disputa. A disputa é apenas uma das fases conflito, reveladora dos interesses confrontados (SERPA, 1999).

\subsection{FASES DO CONFLITO}

Para Rummel (Apud SERPA, 1999:28) a dinâmica do conflito percorre cinco fases distintas e subseqüentes, formando uma espiral ascendente, com o seguinte ciclo:

(i) latente - antes da sua manifestação, são as potencialidades (causas políticas, psicológica e sociais que compõem o conflito, mas não produzem efeitos aparentes) que são transformadas em disposições e objetivos, como por exemplo: a proteção ao meio ambiente, a busca pela qualidade de vida;

(ii) início - a manifestação dos interesses por meio de alguma forma de agressão que gera situação de instabilidade e incerteza. A oposição de interesses e poderes são ativados, explicitados, por exemplo: famílias não possuem local para morar e manifestam sua insatisfação com passeatas ao verificarem que existem terras mal aproveitadas, ou agricultores que precisam desmatar suas propriedades usando fogo, que pode causar incêndio com grave impacto no meio ambiente e nas propriedades circunvizinhas;

(iii) balanceamento de poder - é a administração de forças, momento em que os vetores de poder se chocam ou se inter-relacionam; complexo 
de atitudes que compõe o conflito, ou seja, a disputa. Exemplo: invadir terras alheias, atear fogo na propriedade iniciando um incêndio florestal;

(iv) equilíbrio de poder - momento em que a força dá lugar a resolução, que pode ser alcançada via sentença (poder coercitivo externo à relação de conflito), contrato, justiça (causa e efeito) ou mediação (compleição de interesses);

(v) interrupção do equilíbrio - acomodação das forças e desencadeamento de novo processo.

Pode-se notar que na visão de Rummel, o conflito só é identificado pelas partes envolvidas na sua fase inicial (ii), que corresponde a segunda etapa do processo. Após essa fase, começa o balanceamento de poder (iii) com a confrontação de poderes e a administração das forças, que evolui para a fase de equilíbrio de poder (iv) onde é escolhido o mecanismo de resolução. O ciclo pode terminar nessa fase ou na seguinte, quando ocorre uma interrupção do equilíbrio. Na última fase, a acomodação que conceitua a ordem social é configurada em regras, contratos, acordos que promovem a harmonia social. A promoção da harmonia social, por sua vez, resulta de trabalho dos mecanismos de resolução de disputas.

\subsection{TIPOLOGIA DO CONFLITO}

As tipologias ou classificações do conflito não são globais, mas são importantes para a definição do tipo de mecanismo mais adequado, que possa ser utilizado na resolução do conflito, em que às partes possam alcançar resultados mais eficazes e positivos. As classificações são importantes para este estudo, uma vez que, muitas dessas dizem respeito ao conflito socioambiental.

Serpa (1999) formulou cinco tipologias de conflito, a partir dos estudos de Rummel e Morton, com objetivo de identificar: (i) a relação entre a percepção e a manifestação do conflito; (ii) a esfera de atuação do sujeito; (iii) os interesses; (iv) a natureza; e (v) os efeitos ou resultados. 
Com relação à sua percepção e manifestação, o conflito pode ser classificado da seguinte forma:

(i) real ou verídico - o conflito é percebido com exatidão, há incompatibilidade de objetivos. Para sua resolução utiliza-se o critério objetivo ( $\operatorname{sim}$ ou não) ou a via judicial (adversarial) e extrajudicial (não-adversarial);

(ii) contingente - falta de conhecimento pelas partes da situação. Não é resolvido quando as partes assumem posições rígidas ou não reconhecem a situação;

(iii) deslocado - esconde um conflito real subordinado, e acaba por se manifestar repetidamente mesmo quando solucionado;

(iv) "mal atribuído" - há um equivoco com relação às partes, como o caso do bode expiatório. A sua solução depende da cooperação das partes;

(v) induzido - o conflito existe onde há uma causa política, sendo conseqüência do desequilíbrio do poder. Dificilmente é resolvido pela via extrajudicial;

(vi) latente - são as expectativas do homem, espaço para todos os possíveis conflitos;

(vii) estruturado ou potencial - não pode ser identificado como conflito, precisa da sua declaração;

(viii) falso - não há fundamento para a existência do conflito, houve uma percepção errada da situação.

Segundo a autora, quando o conflito é do tipo contingente, deslocado e "mal atribuído", a mediação é possível, mas é necessário a sua transformação para que o conflito seja percebido com exatidão (real) e assim conseguir obter uma solução duradoura. No 
entanto, quando o conflito é classificado como induzido (político), ou está latente, ou falso (quando há uma percepção errada do conflito), ou é estruturado (não declarado) não é possível a utilização de mecanismo não-adversarial de resolução, como a mediação.

Já no grupo de tipologia de conflitos, em que predomina a esfera de atuação do sujeito, ou partes, ou atores, o conflito é classificado como:

(i) intrapessoal - quando restrito a esfera pessoal. Neste caso será resolvido com terapia;

(ii) interpessoal - entre indivíduos ou grupos com posições antagônicas;

(iii) intragrupal - quando há divergências dentro de um grupo.

Das três classificações desse grupo, interessa para o conflito socioambiental os interpessoal e intragrupal, porém nos exemplos selecionados para este trabalho, verificouse que a esfera de atuação das partes é interpessoal.

Os conflitos pertencentes à tipologia da esfera de interesse, de acordo com a autora, podem surgir em relações particulares (privado), ou em função de interesse comum (público). No conflito socioambiental revelam-se essas duas esferas de interesses.

Outra tipologia de conflito diz respeito à sua natureza. Neste caso, o conflito pode ser:

(i) de dados - falta ou má informação, ou ainda pontos de vista diferentes;

(ii) de interesses - normalmente os conflitos de interesses ocorrem em situações de escassez, situação que viabiliza a utilização da negociação para resolução;

(iii) de estrutura - esfera interna pessoal ou do grupo. A esfera interna pessoal não pode ser resolvida via mediação; 
(iv) de valor - diferentes critérios, cultura e atitudes ou conceitos de justiça e moral, raramente são negociáveis;

(v) de relacionamentos - diferença de entendimento, de percepção ou ausência de comunicação.

O conflito socioambiental pode encerrar tanto conflitos de dados, quanto de interesses, de estrutura interna do grupo, de relacionamentos e de valores.

Finalmente, com relação ao último grupo de tipologia de conflito de Serpa, que trata das conseqüências do conflito, ele pode ser:

(i) destrutivo - quando as partes ficam insatisfeitas com o resultado, sentem-se prejudicadas, normalmente há competição entre as partes, uma ataca a outra; e

(ii) construtivo - quando as partes estão satisfeitas com o resultado, sentem que ganharam na situação conflituosa. Por isso, procuram cooperar para sua resolução, se propondo a atacar o problema.

De acordo com Jandt (Apud SERPA, 1999:32), quando a conseqüência do conflito é construtiva, pode-se: (i) estabelecer limites aos grupos, na medida que fortalece a coesão e a separatividade; (ii) reduzir a tensão; (iii) manter a interação social mesmo quando sob pressão; (iv) clarear objetivos; estabelecer normas; e (v) propiciar o entendimento como resultado ao invés de subordinação ou acomodação.

Observa-se que as cinco tipologias de conflitos de Serpa mostram uma seqüência de ações, que tem inicio com o reconhecimento pelas partes de sua existência e encerra mostrando qual o resultado do conflito para as partes envolvidas. Em outras palavras, essas tipologias de conflitos possibilitam às partes: (i) primeiro, perceber/reconhecer que existe conflito - percepção e a manifestação; (ii) identificar em que esfera de atuação dos sujeitos este se encontra (intrapessoal, interpessoal e intragrupal); (iii) qual o interesse das partes envolvidas - se privado ou público; (iv) qual a origem ou natureza do conflito, se de: falta de dados, interesse (ou disputa de um bem em função de sua escasses), estrutura, valores 
culturais, relacionamentos; e (v) por último, se conflito resultou em algo construtivo ou destrutivo para as partes.

\subsection{ADMINISTRAÇÃO E RESOLUÇÃO DO CONFLITO}

A administração e resolução de conflitos podem ocorrer via decisão judicial, também denominado processo adversarial, "que não propicia a mudança necessária para a evolução que o conflito pode provocar"; ou via extrajudical, processo nãoadversarial, em que é utilizado algum mecanismo alternativo de resolução de disputas como a: negociação, mediação, conciliação, fact finding, ombudsman, arbitragem, entre outros. (SERPA, 1999:32).

Também na visão de Golberg (Apud AZEVEDO, 2002) a administração e resolução de conflitos podem ocorrer via judicial ou extrajudicial, dependendo da esfera do conflito. Para esse autor, há três esferas de conflitos que podem ser administrados e resolvidos de forma diferenciada: (i) os conflito de direitos: que podem ser resolvidos tanto com a utilização de um terceiro como àrbitro do processo, quanto no âmbito judicial; (ii) os conflitos de interesses: podem ser resolvidos via negociação e mediação, pois não discutem direitos, nem provas; e (iii) os conflitos de poder: este é exceção ao ordenamento jurídico, não pode ser resolvido pela via judicial.

Normalmente, a disputa envolve mais de uma esfera de conflito; existem disputas que envolvem as três esferas de conflitos. Ou seja, há disputas que envolvem direitos, interesses e poder. No processo de mediação a esfera maior é sempre a de interesses, porém pode haver intersecção com a esfera de poder e com a de direitos.

Quando o conflito é resolvido via judicial, ele se cristaliza, sendo identificado não mais pela palavra conflito, mas com litígio, que significa, um "conflito de interesse qualificado por uma pretensão resistida". No litígio, reduz-se o conflito a questões dogmáticas, normativas e patrimoniais, colocando-se de lado a satisfação emocional das partes (CITRA; DINAMARCO; GRINOVER, 2002).

Quando a decisão é judicial, ou seja, foi obtida por meio de um litígio, o conflito pode retornar mais grave no futuro, visto que neste procedimento a variável tempo é 
eliminada, para poder demarcar a disputa em um plano de abstração jurídica que permita controlar as variáveis que organizam sua decisão. .

Tradicionalmente os agentes envolvidos no conflito procuram eliminá-lo por meio da utilização da autocomposição ou da heterocomposição. A autocomposição é um processo "díade", prospectivo (voltado para o futuro), onde as partes envolvidas compõem a solução, não há decisões vinculantes, ou seja, não há uma determinação do juiz ou do árbitro que vinculem as partes ao cumprimento de uma obrigação. Dentre as opções de autocomposição encontram-se a negociação, a mediação e a conciliação.

Quando os direitos são disponíveis, ou seja, quando tratam de demanda entre maiores, capazes, sem relevância para a ordem pública, a autocomposição é uma opção dos agentes, que podem fazer uso dos seguintes mecanismos: (i) da desistência - quando o autor desiste da ação antes da citação do réu, ou seja, quando aquele que ajuizou a ação abre mão de continuar com o processo, antes mesmo de ser comunicada a outra parte; (ii) da submissão - quando o réu se submete ao pedido do autor, não oferece resistência; ou (iii) da transação - também denominada de concessões recíprocas, porque as partes envolvidas no processo analisam a questão e abrem mão de pontos que lhes interessam, para chegarem a um acordo. Esta última quando ocorre em juízo é chamada de conciliação, e quando ocorre fora do juízo, é chamada de negociação e mediação (CITRA; DINAMARCO; GRINOVER, 2002).

A heterocomposição é um processo "tríade", retrospectivo (voltado para o passado), onde um terceiro não interessado (arbitro ou juiz) compõe a controvérsia, não atuando no conflito, mas se restringindo aos fatos e as leis, sem nenhum controle das partes envolvidas. O poder de decisão é vinculante. A heterocomposição abrange a arbitragem e a jurisdição (SERPA, 1999).

Observa-se que a escolha do mecanismo de administração e resolução é importante e determina a conseqüência do conflito: construtivo ou destrutivo. Daí a importância de se estudar o conflito em questão, identificando sua fase e as diferentes tipologias, visto que nem todos os conflitos podem ser administrados e resolvidos via processo não-adversarial, ou mesmo processo adversarial, como, por exemplo, o conflito do tipo intrapessoal. 
No contexto atual em que vivemos, ou seja, numa sociedade moderna e complexa, de mudanças constantes tanto no nível social como cultural, "a quantidade de conflitos é potencialmente ilimitada", e entre tantos tipos de conflitos encontramos o conflito chamado de socioambiental que possui características específicas que serão estudadas no próximo tópico (SCHNITMAN, 1999).

\subsection{O CONFLITO SOCIOAMBIENTAL}

Little (2001:111) conceitua o conflito socioambiental como "disputas entre grupos sociais derivadas dos distintos tipos de relação que eles mantém com seu meio natural". Esse conceito envolve tanto a dimensão natural (limitada e complexa), como a dimensão humana, bem assim o relacionamento entre as duas dimensões.

$\mathrm{Na}$ visão de Theodoro (2005:25) os conflitos socioambientais se diferenciam de outras formas de conflito por envolverem recursos naturais, dificilmente enquadrados como "propriedade privada individual", mas enquadrados como bens difusos, que afetam a coletividade, exigindo "mecanismos e instituições capazes de resolver conflitos entre grupos sociais".

Nos dois conceitos acima se nota que o conflito socioambiental é um tipo de conflito que se diferencia dos demais por envolver disputa entre diferentes grupos sociais, em torno de recursos naturais, ou seja, de bens públicos, cuja titularidade de direitos é difícil identificação. Isso empresta a esse tipo de conflito uma característica específica

$\mathrm{Na}$ análise do conflito socioambiental é importante verificar qual é o foco central do conflito, suas características e atores (grupos sociais) envolvidos, para assim identificar as polarizações das posições, as diferentes táticas e estratégias utilizadas pelos atores, mapear alianças e escolher o mecanismo de administração e resolução de conflito mais apropriado.

Com relação ao foco central do conflito socioambiental, Little (2001) identificou três focos de conflitos que giram em torno do: 
(i) controle sobre os recursos naturais - são disputas sobre o acesso, ou sobre a distribuição, ou ainda sobre o controle formal dos recursos naturais, como por exemplo o uso dos recursos florestais;

(ii) impactos ambientais e sociais gerados pela ação humana e natural - o impacto negativo resultante da intervenção humana nos ciclos naturais geram conflitos com relação à contaminação do meio ambiente, ao esgotamento dos recursos naturais e à degradação dos ecossistemas, como por exemplo, o uso do fogo para desmatamento de áreas que serão utilizadas na agricultura pode afetar outras propriedades ou florestas; e

(iii) uso dos conhecimentos ambientais - grupos sociais que possuem conhecimentos ambientais específicos que são utilizados para se adaptarem ao seu ambiente e desenvolverem tecnologias. Os conflitos surgem em torno da percepção de risco pelo uso de novas tecnologias; sobre o controle formal do conhecimento; e, também, em torno dos lugares sagrados. Nesse último caso, o que está em jogo, são valores culturais, tradições e mitos de determinadas comunidades, que são afetadas diretamente pela decisão de grupos econômicos externos de se apropriar de recursos naturais existentes nos lugares considerados pelos membros da comunidade, de "sagrados",

Já a Red Mesoamericana de Manejo de Conflictos Socioambientales (1999) apresenta uma classificação mais detalhada dos conflitos socioambientais que ocorrem na América Latina:

(i) conflitos sobre questões urbanas e rurais;

(ii) conflitos no manejo de áreas protegidas; 
(iii) conflitos em torno da exclusão de uso ou acesso a recursos naturais e conflitos ligados as regras internas de acesso, uso e controle sobre os recursos naturais;

(iv) conflitos ligados a questões de informação, interesses, necessidades, relações humanas;

(v) conflitos dentro da comunidade e entre comunidades vizinhas com interesses diferentes;

(vi) conflitos em torno da: exclusão de algum usuário; ou sobre processos de tomada de decisões coletivas; ou sobre regras para o manejo de recurso e da aplicação destas regras; ou ainda entre instituições do Estado e com o Estado sobre sua função; e

(vii) conflitos assimétricos, segundo as variáveis de poder que se encontram nestes conflitos.

O mesmo estudo apresenta ainda como focos mais freqüentes dos conflitos socioambientais: o uso e acesso a áreas protegidas, terras indígenas, contaminação, concessão florestal, fronteira agrícola, recursos pesqueiros, uso de bosques, mineração, água, exploração petrolífera, manejo de zonas costeiras e manejo de lixo dentre outros.

Percebe-se que o foco dos conflitos socioambientais de Little e da Red Mesoamericana são complementares. Enquanto o primeiro preferiu agrupar os conflitos socioambientais em três grupos distintos, a Red Mesoamericana preferiu apresentar um leque maior de opções, incluindo, questões urbanas e rurais, conflitos ligados a questões de informações, conflitos internos de uma comunidade e conflitos de poder.

No mesmo estudo, a Red Mesoamericana (1999) identificou como características do conflito socioambiental na América Latina:

(i) complexidade e interdependência - normalmente o conflito socioambiental está ligado a um contexto mais amplo que tem a ver com a realidade social, econômica e política da região onde se 
manifestam. Nesses conflitos se entrelaçam temas como a distribuição de renda, as expectativas de desenvolvimento local, a descentralização política, a participação do cidadão, o crescimento da economia nacional e outros. Há uma multiplicidade de interesses econômicos, de conservação, de desenvolvimento local, de defesa da qualidade de vida, do poder estatal frente ao uso dos recursos naturais;

(ii) especificidade - cada conflito sociambiental apresenta uma situação particular onde confluem todos os temas e interesses em diferentes níveis e contextos, sendo difícil identificar o cenário específico em que o conflito socioambiental se desenvolve;

(iii) continuidade e evolução - os conflitos sociambientais são em sua maioria processos sociais contínuos, que evoluem de acordo com a administração adotada, e com os atores e o contexto social em que se desenrolam;

(iv) cenário - estão ligados a regras inter-relacionamento e dependência dos sistemas ecológicos. Muitas vezes, a dinâmica e feitos dos conflitos ultrapassam o cenário político e geográfico aonde se desenvolveram;

(v) informação - devido a grande complexidade desses conflitos surge a necessidade de reunir grande quantidade de informações relacionadas aos aspectos legais, sociais, econômicos e científicos do uso e manejo dos recursos naturais;

(vi) incerteza científica e riscos - há ainda a incerteza que rodeia os aspectos técnicos, o risco natural (extinção de espécies, desastres e etc) e social (perigos para a saúde, deterioração da qualidade de vida, etc); 
(vii) interesse público - os conflitos socioambientais encontram-se dentro da matéria de ordem pública, dada a relevância social de certos temas como a conservação e a saúde. Por outro lado, o Estado deve velar pela proteção do interesse geral da sociedade; o Estado é um ator obrigatório dos conflitos socioambientais;

(viii) interesses não representados - muitos interesses não são representados devido a falta de grupos organizados que se articulem em sua defesa, como também os interesses das gerações futuras que sofrerão as conseqüências das decisões tomadas;

(ix) multiplicidade de atores e instâncias de decisão - na maioria dos casos há mais de um ator nos conflitos socioambientais, como: comunidade rural, ONG local e internacional, governos local, estadual e/ou federal, empresas, cidadão, índios, universidades, igrejas e outros. Da mesma forma, há várias instituições estatais envolvidas na tomada de decisão.

Ainda com relação ao conflito socioambiental, uma instituição brasileira, a Rede de Instituições Capacitoras em Gestão do Desenvolvimento (2005), identificou cinco particularidades, que, de certo modo, complementam as características do conflito socioambiental da Red Mesoamericana. São elas: a indeterminação dos sujeitos, a indivisibilidade de seu objeto, a existência de vínculos fáticos entre os titulares, a transição e mutação no tempo e no espaço, e uma intensa litigiosidade interna.

O estudo da Red Mesoamericana (1999) teve a preocupação de identificar os atores ou partes num conflito socioambiental e suas principais características:

(i) atores coletivos não homogêneos - grupos que representam grande quantidade de indivíduos e interesses;

(ii) diferentes níveis de conhecimento - os atores mostram diferentes níveis de conhecimento e manejo das informações; 
(iii) diferentes recursos e poder - nível de poder diferenciado dos atores e diversidade cultural que refletem no uso e aproveitamento dos recursos.

No conflito socioambiental vários atores atuam, cada um com seu papel, atribuições, competências e responsabilidades. Dentre os atores enumera-se: o Legislativo, o Executivo, o Judiciário, o órgão ambiental dos três níveis de poder, as comunidades afetadas, os empreendedores ou proponentes de novas atividades ou serviços, os empregados e trabalhadores dessas empresas, as empresas de consultoria ambiental, as organizações nãogovernamentais, movimentos ambientalistas da sociedade civil, a imprensa, a mídia, e o Ministério Público.

As dificuldades para solucionar os conflitos socioambientais via judicial são inúmeras, tais como: "supraindividualidade dos bens atingidos, entraves na legitimação para agir, óbices técnicos e de prova, necessidade de providências cautelares etc" (MILARÉ, 2001:93). A jurisdição é a via utilizada para tutelar o meio ambiente, entretanto, existem mecanismos alternativos de resolução, como a mediação, assunto que será abordado no capítulo seguinte, capazes de administrar e buscar uma solução consensual do conflito. 


\section{A MEDIAÇÃO DE CONFLITOS}

A jurisdição estatal não é a única forma de solução de conflitos, existem outros meios alternativos à jurisdição capazes de promover a pacificação social, estes mecanismos são conhecidos como ADR - Alternative Dispute Resolutions, ou RAD Resolução Alternativa de Disputas. A mediação é um desses meios alternativos; ou seja, um processo pacífico e não adversarial de resolução de conflitos; um espaço de criatividade pessoal e social, que valoriza os relacionamentos, incentiva o mútuo respeito e resulta no acesso a cidadania.

\subsection{CONSIDERAÇÕES GERAIS}

Os múltiplos meios alternativos de resolução de disputas existentes oferecem opções não-litigantes, suscetíveis de atravessar diversidade de contextos sociais, capacitando as partes, além de estimar a cooperação e promover a paz. Atualmente a RAD surge como facilitadora nos processos de conflitos e caminho para soluções (SCHNITMAN, 1999).

Na visão americana, os RAD são todos os mecanismos de solução de conflito que não são tratados pelo judiciário, tais como: negociação, mediação e arbitragem. Já na visão de alguns cientistas europeus, o meio alternativo de solução de disputas é a jurisdição estatal, ou seja, a via judicial, porque historicamente os conflitos foram solucionados pela sociedade sem a intervenção do Estado, pois não havia Estado bem organizado (WATANABE, 2003).

Os principais objetivos da RAD são: o menor custo financeiro e emocional, a economia de tempo, a flexibilidade de procedimentos, o adimplemento espontâneo, o sigilo, a preservação dos relacionamentos, a voluntariedade, o controle das partes sobre o resultado, menor recorribilidade e exeqüibilidade (AZEVEDO, 2002). O que contrasta com a realidade vivenciada pelos cidadãos quando se deparam com um processo contencioso judicial. 
Existem mais de quarenta formas de RAD, sendo as principais, segundo Serpa (1999):

(i) negociação - forma básica de resolução onde as partes se encontram diretamente procurando resolver a disputa sem a intervenção de terceiros;

(ii) conciliação - processo informal onde um terceiro atua como elo de comunicação entre as partes, identificando os problemas e possíveis soluções, apaziguando a questão sem se preocupar com a qualidade da solução;

(iii) mediação - "processo informal, voluntário, onde um terceiro intervetor, neutro, assiste aos disputantes na resolução de suas questões", auxilia na comunicação, neutralizando emoções, formando opções e negociando acordo, sem interferir na sua substância;

(iv) fact finding - "realizado mediante a utilização de um perito, neutro, selecionado pelas partes, com o objetivo de encontrar e clarear fatos";

(v) ombudsman - oficial designado pela instituição para investigar queixas e requerimentos com a finalidade de prevenir litígios ou facilitar a sua resolução; e

(vi) arbitragem - processo em que as partes submetem livremente seu caso a uma parte neutra que tem o poder de decisão sobre a disputa.

Atualmente, algumas das formas de RAD são utilizadas no Brasil, como variantes do processo contencioso judicial, como a arbitragem e a conciliação. Os meios alternativos de resolução de conflitos vêm ganhando espaço no ordenamento jurídico brasileiro, visto ser um sistema revolucionário e diferenciado de aplicação da justiça, que rejeitaram os vícios formalistas, bem assim a exagerada documentação e alcançaram a 
desejada celeridade, modificando profundamente o sistema da justiça tradicional (BACELLAR, 2000).

Embora parecidos, a mediação não se confunde com a conciliação, nem com a arbitragem, nem tão pouco com a negociação.

A conciliação é conceituada como um acordo de vontades por meio de concessões mútuas, sendo adequada para resolver situações circunstanciais em que as pessoas não se conhecem, pois não trabalha para a transformação do conflito. A arbitragem é a convenção, que defere a um terceiro que não é juiz, a decisão da lide (BACELLAR, 2000).

Já na negociação não há intervenção de terceiros, pois as partes se encontram diretamente na busca de uma solução que preserve as suas relações, notadamente as relações comerciais. Distintamente das demais, na mediação há a autocomposição assistida, que educa, facilita e ajuda na produção de diferenças que modificam a discórdia (WARAT, 2001).

A mediação é recomendável principalmente para conflitos de múltiplos vínculos, como é o caso dos conflitos socioambientais, pois esta procura preservar e desenvolver as relações (BACELLAR, 2000). Assim, a mediação, como um dos mecanismos de resolução de alternativas de disputas, surge como uma técnica que pode ser utilizada nos conflitos socioambientais, sem com isso eliminar o uso da via judicial ou de outras formas de resolução que possibilitem alcançar uma solução pacífica para o conflito.

Mas o que é a mediação? Quais são os seus objetivos, elementos e princípios? Qual o seu campo de eficácia e seus limites? Quais as suas vantagens e desvantagens em relação à jurisdição estatal? Quais os tipos de mediação? Qual o papel do mediador e do co-mediador no processo de mediação? A mediação pode ser utilizada no conflito socioambiental?

\subsection{CONCEITOS, OBJETIVOS E ELEMENTOS DA MEDIAÇÃO}

Vários são os autores que conceituam mediação na literatura mundial. Dentre tantos autores, escolheu-se aqueles que melhor caracterizam as duas principais correntes de pensamento sobre mediação: a acordista e a transformadora. Essas duas correntes 
de pensamento possuem orientações distintas, divergindo em relação ao objetivo principal da mediação.

$\mathrm{Na}$ corrente de orientação acordista, o principal objetivo da mediação, segundo Warat (2001:84), é o acordo, ou seja, a solução, pois considera "o conflito como um problema a ser resolvido nos termos do acordo". Nessa corrente estão filiados os autores: Moore, Azevedo e Liebman, e Vezzulla.

Na visão de Moore (1998:22), a mediação é conceituada como:

um prolongamento ou aperfeiçoamento do processo de negociação que envolve a interferência de uma aceitável terceira parte, que tem um poder de tomada de decisão limitado ou não autoritário. Esta pessoa ajuda as partes principais a chegarem de forma voluntária a um acordo mutuamente aceitável das questões em disputa. Da mesma forma que ocorre com a negociação, a mediação deixa que as pessoas envolvidas no conflito tomem as decisões.

Azevedo e Liebman (2001:12) conceituam mediação como:

um processo pelo qual um terceiro imparcial facilita a negociação entre pessoas em conflito, as habilita a assumir controle de suas vidas e a encontrar soluções que compatibilizem-se aos seus interesses e necessidades. A mediação é um processo privado, voluntário, informal no qual o mediador, ou mediadores, ajudam as partes a resolver sua disputa de um modo aceitável a todos.

Na visão de Vezzulla (1998:18) a mediação é uma:

técnica de resolução de conflitos não adversarial, que, sem imposições de sentenças ou de laudos e com um profissional devidamente formado, auxilia as partes a acharem seus verdadeiros interesses e a preservá-los num acordo criativo onde as duas partes ganhem.

Verifica-se que os autores da corrente acordista incluem na mediação a figura de um terceiro, como facilitador do processo; este auxilia as partes na tomada de decisão, que deverá culminar num acordo. O foco principal é o acordo e não as relações, ou os vínculos entre as partes envolvidas. 
A segunda corrente, que de acordo com Warat (2001:84), é chamada de transformadora, visualiza o conflito como uma oportunidade de "melhora na qualidade de vida, para o encontro consigo mesmo e para a melhora na satisfação dos vínculos", não tendo por finalidade o acordo e sim a administração do conflito. Essa corrente está representada neste estudo por Warrat e Six.

Para Warrat (2001:75) a mediação é:

um procedimento indisciplinado de auto-eco-composição assistida (ou terceirizada) dos vínculos conflitivos com o outro em suas diversas modalidades. Indisciplinado por sua heteroxia já que do mediador se requer a sabedoria necessária para poder se mover, sem a obrigação de defender teorias consagradas, um feudo intelectual ou a ortodoxia de uma capela de classes ou do saber. A autocomposição dos procedimento de mediação é assistida ou terceirizada, porquanto se requer sempre a presença de um terceiro imparcial, porém implicado, que ajude as partes em seu processo de assumir os riscos de sua auto-decisão transformadora do conflito.

Na visão de Six (2001:257) a mediação consiste:

em estabelecer ligações onde elas ainda não foram feitas, suscitar o agir comunicacional onde não existe. [...] Trata-se, então, na mediação de estabelecer constantemente novas relações entre uns e outros, numa verdadeira criatividade; ou ainda de reparar laços que se distenderam ou foram submetidos a qualquer dano; ou ainda gerencia rupturas de ligações, desavenças.

Os autores da corrente transformadora, apesar de também incluírem a figura de um terceiro, apresenta uma outra visão de mediação. Warrat e Six destacam os vínculos e as relações das partes como foco principal da mediação. Já o mediador além de assistir as partes está implicado no processo, na medida que gerencia os vínculos, promove a reparação desses vínculos e educa a partes para assumirem as decisões tomadas.

Apesar da divergência com relação ao objetivo principal da mediação, em todos os conceitos acima citados há um ponto comum: o diálogo entre as partes, suscitado pelo mediador. O diálogo é o meio pelo qual ocorre a administração e solução pacífica do conflito, estabelecendo novos relacionamentos que possibilitam uma boa convivência futura, 
a prevenção de novos conflitos e também a inclusão social, pois possibilita reflexão dos direitos e deveres de cada parte.

Outro ponto convergente das duas correntes diz respeito à distinção entre a mediação e o litígio. "A mediação não se preocupa com o litígio, ou seja, com a verdade formal contida nos autos", mas visa auxiliar as partes para que realizem uma confrontação construtiva do conflito, no seu campo temporal. Isto é, o oposto do litígio, visto que este, além de possuir uma visão negativa do conflito, congela-o no tempo para demarcá-lo e controlar as variáveis que são necessárias para a tomada de decisão, reduzindo-o a questões de direito ou patrimônio (WARAT, 2001:80).

Há, ainda, outros objetivos abraçados pelas duas correntes que tratam da mediação, como: resolução das diferenças entre as partes, redução dos obstáculos de comunicação, consideração das necessidades envolvidas, maximização do uso de alternativas, preparação dos participantes para que possam aceitar as conseqüências de suas decisões, redução dos efeitos negativos do conflito e a produção de um plano de ação para o futuro (SERPA, 1999).

Em todos os conceitos mencionados encontra-se a presença dos seguintes elementos na mediação: as partes, o conflito e o mediador. O primeiro elemento diz respeito a toda e qualquer pessoa, natural ou jurídica, pública ou privada, nacional ou internacional, ou grupo de pessoas. O segundo elemento, o conflito, que pode englobar diversos tipos de conflitos, deve ser trabalhado na sua dimensão construtiva. Por último, o mediador, é o terceiro neutro que facilita a comunicação das partes.

\subsection{PRINCÍPIOS DA MEDIAÇÃO}

A mediação está apoiada nos seguintes princípios: da neutralidade e imparcialidade de intervenção, da autonomia de vontades ou consensualismo processual, da confidencialidade, da decisão informada, do pax est querenda, da capacitação ou empoderamento, e o princípio da validação. Além desses, também fundamentam a mediação os princípios informativos dos juizados especiais, de que trata o Art. $2^{\circ}$ da Lei 9.099/95: a informalidade, oralidade, simplicidade, economia processual e celeridade (AZEVEDO 2002). 
Segundo o princípio da neutralidade e imparcialidade de intervenção, o terceiro, ou terceiro interventor, ou mediador, é aquela presença neutra (quanto ao objeto) e imparcial (quanto às partes), capaz de criar uma nova dinâmica e auxiliar na solução do processo. Com isso, fica assegurado a não interferência do mediador na tomada de decisão, além da ausência de favoritismos e preconceitos (AZEVEDO, 2002).

O princípio da autonomia de vontade ou consensualismo processual, também chamado de princípio da não-adversariedade - consiste no poder que as partes têm de decidir quanto ao processo (consensualismo processual), visto que o mediador não decide (SERPA, 1999).

Já o princípio da confidencialidade norteia todo o processo de mediação, que é de natureza privada. As informações são restritas ao âmbito das partes e do mediador, podendo haver publicidade somente com autorização destes. Também estabelece que o mediador não pode ser testemunha, de qualquer das partes, em processos futuros - é o chamado sigilo profissional (AZEVEDO, 2002).

No princípio da decisão informada a parte chega ao acordo conhecendo toda a gama de alternativas e sabendo o que diz o direito. Apesar de o mediador não poder dar orientação jurídica, ele pode interromper a sessão e pedir que as partes consultem seus advogados (AZEVEDO, 2002).

Pelo princípio pax est querenda, o direito e o processo compõem um só elemento, escopo supremo em que a paz é sempre buscada. Assim, o escopo que permeia todo o processo da mediação é a busca da paz (AZEVEDO, 2002).

No princípio da capacitação ou empoderamento há a restauração do senso de valor, pois as partes são educadas para a solução do conflito (AZEVEDO, 2002).

Já o princípio da validação estimula o comportamento empático da parte, de modo a compreender os sentimentos da outra parte envolvida, validando interesses e sentimentos mútuos, emprestando o potencial transformador ao processo (AZEVEDO, 2002).

O princípio da informalidade sustenta o processo de mediação, pois este não está submetido a nenhuma norma de direito processual. A informalidade do processo de 
mediação é o princípio que esclarece que a mediação não está presa a normas rígidas, sendo sua estruturação dependente das partes (SERPA, 1999).

O princípio da oralidade está ligado ao procedimento, e aponta para a necessidade da predominância do aspecto oral, afastando uma das causas de lentidão do processo que é a predominância do escrito. Predomina na mediação a forma oral como mandamento precípuo, "embora sem a eliminação do uso dos registros da escrita" (THEODORO JÚNIOR, 2001:421).

Os princípios da simplicidade, celeridade e economia processual, junto com o princípio da informalidade, valem como uma advertência ao mediador para que não se prendam a formas, procedimentos, ou a qualquer uniformidade que engessem o processo de mediação ((THEODORO JÚNIOR, 2001).

Observa-se que os princípios que permeiam o processo de mediação do conflito tende a servir de orientação para o estabelecimento de procedimentos a ser utilizado em tal processo, de modo a torná-lo o mais flexível possível, para que as partes possam chegar a um acordo que atenda aos seus interesses.

\subsection{MEDIAÇÃO: VANTAGENS, DESVANTAGENS, EFICÁCIA E LIMITES}

Os dois itens anteriores deste capítulo apresentam partes teóricas sobre a mediação, sem, entretanto, entrar no mérito das vantagens e desvantagens que um processo de mediação oferece às partes envolvidas, em quais situações a utilização do mecanismo da mediação pode apresentar resultado eficaz, e quais conflitos podem ser resolvidos pela mediação de acordo com os parâmetros estabelecidos pelo Direito. Estes são, portanto, os temas a serem abordados a seguir.

\section{Vantagens e desvantagens da mediação}

Como a mediação é um processo voluntário, embasado nos princípios anteriormente descritos, ele possui vantagens e desvantagens em relação ao processo judicial.

As vantagens do processo de mediação em relação ao processo judicial foram bem detalhadas por Cooley (2001), e estão sintetizadas a seguir: (i) a privacidade; (ii) o 
controle do foro pelas partes; (iii) a escolha do mediador pelas partes; (iv) a reprodução das preocupações e das prioridades da disputa; (v) a flexibilidade (exigências processuais mínimas); (vi) a educação das partes; (vii) o cuidado dos problemas básicos; (viii) a busca por soluções criativas; (ix) a busca de um alto grau de comprometimento das decisões; (x) a redução do custo (é relativamente barata).

O processo de mediação, por ser particularizado a cada caso, possibilita um maior controle das partes envolvidas, uma maior autonomia. Além disso, proporciona uma maior satisfação das partes, o que leva a um maior empenho no cumprimento do acordo; tanbém trabalha os vínculos existentes evitando o desgaste e promovendo um futuro mais harmônico.

A uso da mediação contribui para a pacificação social e harmonia entre as pessoas. Para Bacellar (2000) somente se alcançará a verdadeira justiça quando os casos forem solucionados mediante consenso, que resolva não só a parte dos problemas em discussão, mas também todas as questões que envolvam o relacionamento todos os interessados.

Segundo Cooley (2001), a mediação também tem suas desvantagens em relação ao processo judicial: (i) o mediador não tem poder para impor acordos; (ii) não se pode forçar a participação das partes; (iii) não há salvaguardas de devido processo (a parte não pode ser obrigada pela intimação, etc.); (iv) uma parte poderosa pode influenciar no resultado; (v) não é vinculante; (vi) não aplica ou desenvolve normas ou padrões públicos; (vii) o resultado não precisa ser baseado em princípios.

Observa-se que apesar das desvantagens da utilização da mediação enumeradas por Cooley, sabe-se que a mediação se constitui em apenas mais um mecanismo disponível de resolução de conflitos, que pode ser utilizado pelas partes envolvidas, quando percebem a existência de conflitos.

Como dito no capítulo anterior, nem todos os conflitos podem ser solucionados via processo de mediação, daí a importância de se identificar qual a sua natureza, a esfera de atuação dos sujeitos e os interesses envolvidos para verificar a possibilidade de seu uso. 
Na realidade, a mediação não visa substituir a jurisdição, mas oferecer um outro meio de solução pacífica à sociedade aliada ao judiciário. A sua utilização reduziria a quantidade de processos judiciais, contribuiria para o estabelecimento do diálogo entre as partes envolvidas, para o desenvolvimento da solidariedade e para a transformação social.

\section{Eficácia e limites da mediação}

A mediação é um mecanismo de resolução de disputas vantajoso, produzindo todos os seus efeitos, entre eles a pacificação social e harmonia entre as partes, quando utilizada em determinados tipos de conflito, dentro do vasto universo de conflitos.

Para Serpa (1999) a mediação é eficaz quando utilizada nas seguintes disputas: comercial; civil; industrial; trabalhista; família; questões gerais de vizinhanças e comunitárias; questões sobre normas públicas, tais como o uso da terra e questão ambiental; conflitos sociais (raciais, polícia e comunidade) e conflitos internacionais.

Para Moore (1998), a mediação é eficaz quando a natureza do conflito é: de dados (quando há falta ou má informação), de interesses (quando há situações de escassez), de estrutura interna do grupo, de valores (diferentes culturas), e de relacionamentos. O mediador analisa a raiz do conflito, identificando o tipo ou tipos de conflitos envolvidos na disputa, intervindo por meio do uso de estratégias adequadas para a abordagem do(s) conflito(s).

Para Warrat (2001) a mediação será eficaz em qualquer tipo de conflito, que envolva disputas: comunitária, ecológica, empresarial, familiar, penal, relacionada ao consumidor, trabalhista, política, de realização dos direitos humanos e da cidadania, e de menores em situação de risco, dentre outras. O uso da mediação nos conflitos que envolvam a afetividade e não exclusivamente o patrimônio, acarreta a realização da autonomia, da cidadania e da democracia.

Desta forma, pode-se inferir que para os autores citados a mediação é um mecanismo eficaz em questões socioambientais, visto que estas envolvem tanto conflitos de dados, quanto de interesses, estrutura, valores e relacionamentos, além de envolver afetividade e promover a cidadania e a democracia. 
Com relação aos limites da mediação, ou seja, as áreas do Direito que possuem competência para usar da mediação, encontram-se algumas visões diferenciadas. A princípio, os conflitos em que o Estado faça parte não podem ser objeto de mediação, como no caso dos conflitos de natureza administrativa, tributária e previdenciária. Entretanto, se houver previsão legal para o uso de transação ou conciliação será possível o uso da mediação (SALES, 2003).

Na visão de Citra, Dinamarco e Grinover (2002:29), a mediação é admitida sempre "que não se trate de direitos tão intimamente ligados ao próprio modo de ser da pessoa, que a sua perda a degrade a situações intoleráveis". Assim, não será admitida a mediação quando os direitos da personalidade (vida, liberdade, honra, etc) são atingidos, uma vez que ocorre indisponibilidade dos interesses da parte alcançada, podendo ser a mesma do tipo objetiva (matéria penal) ou do tipo subjetiva (incapacidade e pessoas jurídicas de direito público).

Como o ordenamento jurídico brasileiro admite a conciliação nos conflitos de natureza cível que versem sobre direitos disponíveis (artigo 331 do Código de Processo Civil), ou de menor complexidade (Lei 9.099/95), e a transação nos conflitos de direitos patrimoniais de caráter privado (artigo 841 do Código Civil); a mediação pode ser utilizada nos conflitos socioambientais, pois não há direitos personalíssimos envolvidos (SALES, 2003).

Até mesmo os conflitos penais também podem ser objetos de mediação, quando for o caso de ação penal privada, visto que dependem da propositura do ofendido ou de seu representante legal. Há neste caso a disposição do direito de ação, o que não ocorre na ação penal pública e nas matérias tratadas nos juizados especiais criminais (SALES, 2003).

Na visão de Riskin (2002) a mediação pode ser utilizada por "uma grande gama de atividades", sendo que algumas dessas atividades não possuem ou possuem poucos pontos em comum, não havendo sistema lógico que o classifique. Entretanto, há a seguinte discussão: se a mediação deve ou não "ser empregada nos casos que envolvam direitos constitucionais, violência doméstica ou atividade criminosa". Mesmo essa visão não limita o uso da mediação nos conflitos socioambientais. 
Ressaltamos, que no ordenamento jurídico brasileiro encontramos os conflitos trabalhistas, que apesar de serem irrenunciáveis (Art. $9^{\circ}$ da Consolidação das Leis do Trabalho), comportam várias normas que possibilitam o uso da mediação, como: Lei 9.958/00, Decreto $n^{\mathrm{o}}$ 1.256/94 e 1.572/95, Portaria do Ministério do Trabalho $\mathrm{m}^{\mathrm{o}}$ 817/95, 818/95 e 3.122/98 (SALES, 2004). Portanto, não há nenhuma norma legal ou doutrina que limite o uso da mediação nos conflitos socioambientais.

\subsection{TIPOS DE MEDIAÇÃO}

Dentre as várias orientações, estratégias e técnicas que o mediador pode utilizar no processo de mediação, Riskin (2002) distingue quatro tipos de mediações baseadas em duas linhas básicas: o âmbito dos problemas e a atividade do mediador, traçadas num plano cartesiano. A primeira linha, âmbito dos problemas, está representada em um eixo cartesiano horizontal, onde no extremo direito os problemas estão definidos de forma ampla e no extremo esquerdo os problemas estão definidos de forma restrita.

A segunda linha, atividade do mediador, está representada em um eixo cartesiano vertical. $O$ mediador desempenha sua função considerando que as partes "querem e precisam de orientação para chegarem a uma situação propícia ao acordo", caracteriza a mediação do tipo avaliadora (na parte superior do eixo). Já o mediador que auxilia as partes a buscarem a compreensão dos conflitos e a desenvolverem soluções criativas por elas mesmas, caracteriza a mediação do tipo facilitadora (na parte inferior do eixo).

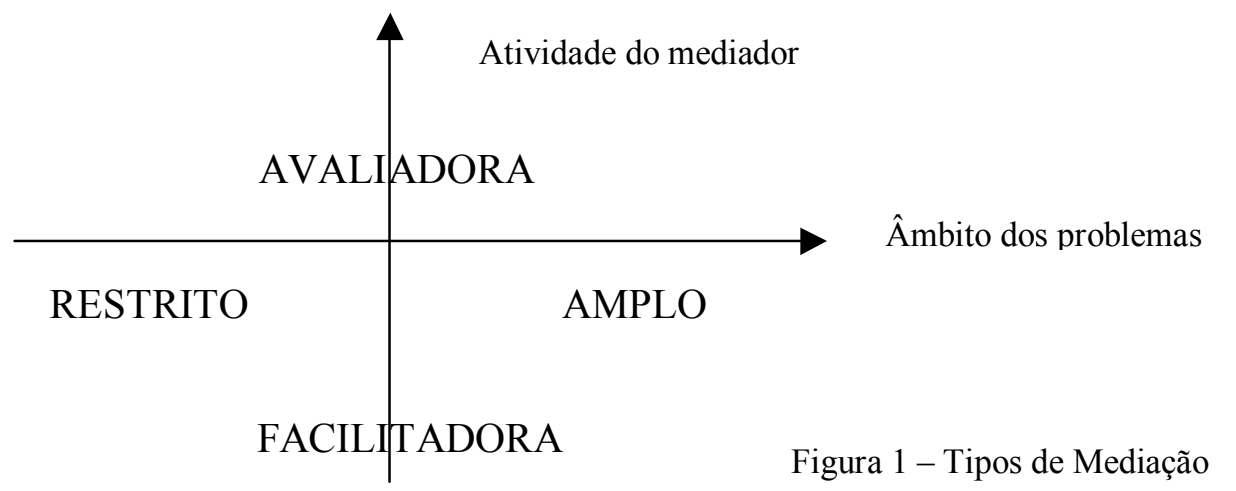

Desta forma, encontramos no canto superior esquerdo um mediador do tipo avaliador para problemas restritos, no canto superior direito o mediador será também 
avaliador, mas para problemas amplos. No canto inferior esquerdo encontramos o mediador facilitador para problemas restritos e no canto inferior direito o mediador facilitador para problemas amplos.

Para Riskin (2002), quando a mediação tem como principal meta fixar o objeto sob litígio (dirimir pontos específicos) gerando um acordo, a mediação é do tipo restritiva (à esquerda no eixo). Mas se a mediação trata de vários interesses, sendo seu foco mais amplo, buscando identificar toda a gama de conflitos existentes na disputa, a mediação é do tipo ampla (à direita no eixo).

Utilizando os padrões de mediação definidos acima, o tipo de mediação que melhor se encaixa aos moldes da corrente transformadora é a mediação facilitadora-ampla. E no caso da corrente acordista, a mediação é restritiva, dirimindo pontos específicos, podendo variar de graduação entre a avaliadora e a facilitadora. No caso do conflito socioambiental o tipo facilitador-amplo é o que melhor se encaixa, devido à gama de problemas que normalmente estão envolvidos no conflito.

Six (2001) tem uma outra visão dos tipos de mediação. Para o autor há somente dois tipos de mediação: a mediação institucional e a mediação cidadã, que podem conviver simultâneamente. O primeiro tipo se caracteriza por ser uma mediação emitida por um poder proveniente de algum organismo, ou instituição. Neste caso, o mediador cumpre um trabalho específico a serviço da instituição e dos clientes desta, sendo um especialista formado para atender um problema específico, bem definido, pelo qual irá responder. Este tipo de mediador é pressionado pela instituição para chegar a soluções rápidas.

A mediação cidadã se caracteriza por nascer dos grupos sociais e não de instituições. Os mediadores não são juízes, têm apenas autoridade moral, são cidadãos entre cidadãos, destinados a encontrar pessoas que estão em situação de conflito. "Os mediadores cidadãos fazem então apelo aos recursos próprios das pessoas que os procuram”, despertando tais recursos e ajudando a colocá-los em aplicação para que seja encontrada uma solução adequada para o conflito. A forma de agir dos mediadores conta com o tempo, que é determinado pelas partes e pelo mediador, e com o espaço ou lugar de mediação que não deve ser anexo ao tribunal (SIX, 2001). 
No conflito socioambiental a mediação é cidadã, pois nasce dos grupos sociais envolvidos nos conflitos, apesar de poder existir uma instituição, ou melhor, um local pré-determinado onde as partes envolvidas podem se encontrar e junto com o mediador buscar uma solução criativa para a disputa.

\subsection{PAPEL DO MEDIADOR}

O mediador pode ser qualquer tipo de profissional na visão de Serpa (1999). Ele é um "terceiro interventor, que, mediante técnicas apropriadas ligadas à negociação, dirige as partes para uma solução de valor mútuo". Independente do tipo de mediação e do conflito, esse terceiro interventor pode assumir diferentes papéis na tentativa de auxiliar as partes a solucionarem o conflito.

Em geral o mediador pode desempenhar diversos papéis. Moore (1998) identifica alguns desses:

(i) facilitador da comunicação, aquele que promove o diálogo;

(ii) legitimador, aquele que ajuda todas partes a reconhecerem o direito uma das outras;

(iii) facilitador do processo, ou seja, o que preside o processo;

(iv) treinador, instruindo as partes quando for necessário;

(v) ampliador de recursos, aquele que proporciona assistência de especialistas às partes;

(vi) explorador do problema, que examina o problema de várias perspectivas;

(vii) agente da realidade, que auxilia na confecção de um acordo viável;

(viii) bode expiatório, aquele que assume responsabilidade por decisão que não agrada as partes; 
(ix) líder, aquele que toma a iniciativa de prosseguir as negociações através de sugestões.

Apesar dos múltiplos papéis a ser desempenhado pelo mediador, o principal papel a desempenhado em qualquer tipo de mediação é o de propiciar a comunicação entre as partes, permitindo que elas definam e expressem a sua discordância. O mediador fará o controle desta comunicação, gerindo a comunicação para criar processos integradores, impedindo diálogos improdutivos e subdividindo questões, para que as mais fáceis sejam trabalhadas em primeiro lugar (SCHNITMAN, 1999).

Assim, "o núcleo da mediação em seu sentido original e amplo concentra-se na facilitação da negociação mediante a criação de um novo contexto de comunicação de apoio e no emprego de outras habilidades que não envolvem a aplicação do direito". O mediador amplia as opções de resolução do conflito indo além dos pontos jurídicos envolvidos, pois auxilia as partes a se comunicarem e a realizarem escolhas voluntárias e conscientes. Ele deve controlar o processo e não o conteúdo ou resultado, não podendo dar conselhos, recomendações ou assessoramento (SCHNITMAN, 1999).

O mediador usa "a parte direita do cérebro", responsável pelos processos criativos, lidando com o subjetivo, participando ativamente na tentativa de "levar as partes à reconciliação e ao acordo independente de quem ou o que está certo ou errado" (COOLEY, 2001: 27).

Tanto na corrente acordista como na transformadora o mediador pode desempenhar diferentes papéis, porém destacam-se alguns desses papéis quando da adoção de uma das correntes.

$\mathrm{Na}$ corrente transformadora, o papel do mediador é provocar, estimular, ajudar as partes a se olharem, se reconhecerem. Não é intervir no conflito, interpretar, ou transformá-lo, mas ajudar as pessoas à "sentir o sentimento", olhando a si mesmas e não o conflito. $\mathrm{O}$ mediador auxilia as partes a procurarem um acordo interiorizado, que tenha como base uma negociação transformadora, e não só um acordo de palavras (WARRAT, 2001). 
Nesta corrente, o mediador é um "terceiro imparcial, porém implicado", que ajuda as partes a assumirem os riscos da sua "autodecisão transformadora do conflito" (WARRAT, 2001:75). Por outro lado, o mediador não tem o poder de decidir o conflito, mas apenas de ajudar as partes, criando espaços transacionais, e retirando do conflito o seu efeito destrutivo.

Na corrente acordista, o mediador usa essencialmente o diálogo para ajudar as partes a resolverem os conflitos, por meio do exame de seus interesses e necessidades, e, assim, negociar. Não há a obrigação de negociar, mas sim a tentativa de realização de um acordo. O mediador contribui com a introdução de novas dinâmicas que facilitam a interação das partes (MOORE, 1998).

Apesar da colocação particular de cada corrente, nenhuma delas contradiz quanto ao papel principal do mediador no processo de mediação, que é o de propiciar o diálogo, facilitando a comunicação entre as partes, o conhecimento mútuo, a interação.

\subsection{ETAPAS DE UM PROCESSO DE MEDIAÇÃO}

Da mesma forma que o processo na visão jurisdicional é a força que motiva a prática dos atos do procedimento, o processo de mediação é o todo formado por fases, ou seja, procedimentos encadeados. Se por um lado não existem regras rígidas de procedimento na mediação, nem uniformidade; por outro lado, há um procedimento flexível, visto que seu propósito é assegurar maior eficácia do processo de mediação, que responde a princípios, técnicas, ritos e estratégias que procuram revisar o conflito.

Para Azevedo (2001), o procedimento de mediação possui nove estágios, que abrange todo o processo, isto é, do primeiro contato até o monitoramento do cumprimento do acordo entre as partes:

(i) preparação para a mediação: onde ocorre os primeiros contatos com as partes havendo um explicação do papel do mediador (propiciar o diálogo). O mediador faz um planejamento do formato da mediação, estruturando o local e se reunido com o co-mediador (se for o caso); 
(ii) início da mediação: declarações de abertura da mediação e apresentação das partes e do mediador. Momento em que o mediador inicia a sessão, ajudando as partes a ouvirem, a se sentirem ouvidas, formando um vínculo de confiança entre o mediador e as partes;

(iii) reunião de informações: momento em que as partes fazem as suas declarações e o mediador escuta e formula perguntas;

(iv) identificação de questões, interesses e sentimentos: o mediador faz um sumário das questões, interesses e sentimentos envolvidos no conflito, com enfoque nas necessidades das partes, bem assim com enfoque prospectivo, de modo a preservar a sua neutralidade;

(v) esclarecimento das controvérsias e dos interesses: momento de discussão das controvérsias, de reconhecimento pela partes dos interesses e sentimentos em jogo;

(vi) resolução dos problemas: as partes avaliam os possíveis métodos de resolução e as opções selecionadas em busca do consenso;

(vii) geração do acordo: confirmação e redação do acordo, ou se houver impasse passa-se a discussão de opções a serem tomados;

(viii) encerramento da mediação: revisão do acordo verbal ou escrito, ou no caso do impasse passa-se a revisão das questões e interesses das partes e das opções;

(ix) monitoração do acordo: a gestão da qualidade do acordo.

Anterior a essa formulação do processo de mediação efetuada por Azevedo, Vezzulla (1998) dividia o processo de mediação em seis etapas: (i) apresentação do mediador e das regras da mediação; (ii) exposição dos problemas pelas partes; (iii) resumo e primeiro ordenamento dos problemas; (iv) descoberta dos interesses ainda ocultos; (v) geração de idéias para resolver os problemas (acordos parciais); e (vi) acordo final.

Dessa forma, pode-se verificar que Azevedo melhorou e inovou Vezzulla, acrescentando as etapas de preparação para a mediação e monitoração do acordo, bem assim, detalhando melhor as demais etapas. 
Também Moore (1998) descreveu o processo de mediação de uma forma mais detalhada, na mesma época que Vezzulla, e anterior a Azevedo. Para ele esse processo varia de acordo com a cultura, a ênfase e a abordagem, mas de modo geral há doze estágios, onde as cinco primeiras etapas são de preparação, ou sejam antecedem ao início da sessão de mediação.

Na visão de Moore (1998) as etapas do processo de mediação estão assim definidos:

(i) o estabelecimento do relacionamento com as partes,

(ii) a escolha da estratégia para orientar a mediação,

(iii) coleta e analise das informações básicas,

(iv) identificação de estratégias que permitam a construção de um plano para a mediação,

(v) construção da confiança e da cooperação,

(vi) iniciação da sessão de mediação,

(vii) definição das questões e estabelecimento de uma agenda para tratamento das questões

(viii) identificação dos interesses ocultos das partes,

(ix) geração de opções para o acordo,

(x) avaliação das opções de acordo,

(xi) barganha final, e

(xii) acordo formal.

Nota-se que a primeira etapa do processo de mediação apontada por Azevedo é a da preparação para a mediação, que engloba as cinco primeiras etapas de Moore, ou seja, é uma preocupação pré-processual, onde é determinado o mediador adequado e imparcial que deverá assistir as partes. $\mathrm{O}$ mediador entra em contato com os envolvidos no conflito, verificando a voluntariedade dos mesmos e marcando a sessão inicial, estruturando o local onde serão realizadas as reuniões, e se for necessário, reunindo-se com o co-mediador (AZEVEDO, 2001). 
A fase seguinte corresponde ao início da mediação. O mediador faz a sua apresentação, explicando o papel de cada um: das partes, do mediador, do co-mediador (se for o caso) e do advogado no processo; também, descreve o processo de mediação, explica o princípio da confidencialidade e suas exceções (acordo ilegal, crime). Nesta etapa a preocupação principal é a compreensão e o engajamento das partes no processo de mediação, bem assim a criação de um vínculo de confiança entre as partes e o mediador. Em seguida, começa a reunião de informações através das declarações das partes, da formulação de perguntas e escuta ativa do mediador. As questões, interesses e sentimentos envolvidos no conflito são identificados, para que o mediador possa usar de ferramentas que provoquem a participação, a criatividade e a mudanças das partes em busca de um consenso que culmine na transformação do conflito (AZEVEDO, 2001).

Dentro desse processo de mediação, várias técnicas podem ser utilizadas, como o questionamento direto, o brainstoming, a discussão orientada para o interesse; dependendo dos conflitos e da área de direito substantivo envolvida (MOORE, 1998).

Caso seja necessário, poderão ser acordadas previamente (no início da mediação), o uso de reuniões privadas (caucus), a fim de permitir que sentimentos sejam liberados sem aumentar o conflito, bem assim eliminar a comunicação improdutiva, e quebrar impasse, dentre outros (AZEVEDO, 2001).

A finalização da mediação ocorre quando as partes conseguem chegar a um consenso, em forma de acordo, sobre a totalidade da disputa ou sobre parte dela, ou quando há um impasse que impossibilita qualquer acordo (AZEVEDO, 2001).

Os três tipos de procedimentos acima mencionados apresentam pontos comuns como: o inicio do processo, a identificação e ordenamento das questões e interesses (inclusive os ocultos), geração de opções de acordo e o acordo final. Entretanto, Azevedo é o único que se preocupou com a monitoração do acordo, que é fundamental para os casos que envolvem conflitos socioambientais.

Pelo modo como os autores abordaram os procedimentos da mediação podese inferir que para os conflitos socioambientais o ideal é adotar aquele proposto por Azevedo, 
por apresentar uma multiplicidade de etapas que podem tanto ser suprimidas ou ampliadas, dependendo da complexidade do conflito.

Deve-se salientar que, quando se trata de disputa complexa ou quando as partes possuem diferenças étnicas, culturais, ou há múltiplas partes, normalmente se utiliza o processo de co-mediação, no qual mais de uma pessoa funciona como mediador, normalmente de especializações diferentes e que combinem com as partes em conflito, a fim de trazer mais confiança ao processo de solução consensual de conflitos. Entretanto, o co-mediador não pode ser confundindo com o perito que é nomeado ad hoc pelo juiz para realizar um trabalho técnico especializado, examinar a situação, fazer vistorias ou avaliações (COOLEY, 2001). 


\section{A MEDIAÇÃO NA RESOLUÇÃO DOS CONFLITOS SOCIOAMBIENTAIS}

A questão ambiental possui múltiplas faces e implicações, além de inspirar conflitos entre o governo e a sociedade, visto que o direito ao ambiente sadio é um direito fundamental individual amparado na Constituição Federal de 1998.

Neste capítulo, analisa-se a possibilidade de utilizar a mediação como uma ferramenta de ajuda à resolução consensual de conflitos socioambientais. A idéia é verificar se na legislação constitucional e infraconstitucional (legislação ambiental) existe mecanismo que possa amparar a utilização da mediação nos conflitos socioambientais, inclusive se esse processo pode ocorrer num espaço institucional, que possa facilitar o exercício da cidadania e da democracia, onde os conflitos socioambientais possam ser discutidos, por meio do diálogo facilitado pelo mediador.

\subsection{CONSIDERAÇÕES GERAIS}

Atualmente no Brasil o meio usual de resolução de conflitos é a via judiciária. Os meios alternativos estão em fase de organização: a arbitragem já está institucionalizada na Lei $n^{\circ} 9.307 / 96$, e a conciliação está institucionalizada na Lei $n^{\circ}$ 9.099/95.

Com relação à mediação existe um Anteprojeto de lei que institucionaliza a mediação no processo civil, estabelecendo o procedimento que deve ser observado para todas as causas civis, exceto as que foram dispostas no Art. $5^{\circ}$ do referido Anteprojeto ${ }^{2}$. E, na área trabalhista encontramos as Leis $n^{\circ} 10.101 / 00$ e $n^{\circ} 10.192 / 01$, bem assim decretos e portarias do Ministério do Trabalho e Emprego (MANUAL DO MEDIADOR, 2001), que disciplinam o uso da mediação.

\footnotetext{
${ }^{2}$ Ver Anexo B.
} 
Também encontramos no Brasil, a mediação cidadã, assim chamada por Six, exercida por órgãos não jurisdicionais, como o Projeto Justiça Comunitária e outros, mesmo que atuando junto ao juiz. E ainda nos deparamos com a proposta de criação de câmaras de mediação ambiental.

Do ponto de vista histórico, os meios alternativos de resolução de disputas não são completamente estranhos ao nosso ordenamento jurídico, pois desde a época do império, apenas dois anos após a independência do Brasil, encontramos o uso da conciliação. O Art. 160 da Constituição Imperial de 1824 dispunha que na causas cíveis, e nas penais civilmente intentadas as partes poderão nomear árbitros. As sentenças desses árbitros serão executadas sem recurso, se assim as partes convencionarem (WATANABE, 2003).

Já o Art. 161 daquela Constituição fixou que somente começar-se-á um processo se constar que se tenha intentado o meio de reconciliação, ou seja, não seria admitida uma causa em juízo sem a tentativa de conciliação. E o Art. 162 determinou que para aquele fim haveria Juizes de Paz, eleitos pelo mesmo tempo e maneira pelo qual se elegem os Vereadores das Câmaras. Assim, na tentativa de conciliação haveria juizes de paz eleitos pelo povo (WATANABE, 2003).

O juiz de paz tinha uma atribuição conciliatória prévia dentro da circunscrição do distrito. Esta conciliação era obrigatória para propositura de qualquer processo, e não era exigido o bacharelado em Direito do juiz de paz. Entretanto, esta figura, ao longo da história constitucional, perdeu muito das suas atribuições, até que no regime militar passou a ser mero juiz de casamento (LENZA, 2002).

Os historiadores afirmam que o juiz de paz foi uma concepção dos liberais contra os conservadores para fazer face ao excessivo autoritarismo do estado, pois todos os conflitos eram solucionados pelo Judiciário. Entretanto, a instituição do juiz de paz não se manteve, apesar de aparecer nas Constituições Federais como uma função jurisdicional e pacificadora (WATANABE, 2003).

A Constituição Federal de 1988 revigora os juizados de paz, "oferecendo a oportunidade de serem eleitos por quatro anos, dando-lhes função de conciliação nãojurisdicional e sobretudo remuneração pelo Tesouro Estadual” (LENZA, 2002). 
Isto demonstra que a cultura do povo brasileiro se tornou dependente de autoridade, não havendo organização da sociedade em termos de trabalho coletivo e os mecanismos de resolução alternativa de disputas necessitam de terreno fértil para prosperar, isto é, de uma mentalidade receptiva a estes moldes de tratamento de conflito (WATANABE, 2003).

Essa mentalidade está começando a ser modificada com as recentes inclusões no nosso ordenamento jurídico da conciliação e da arbitragem, e mesmo da mediação no âmbito do Direito do Trabalho. Sem contar com o trabalho de órgãos jurisdicionais como o TJDFT, que possui um programa de mediação familiar; da sociedade e de órgãos não jurisdicionais.

\subsection{A MEDIAÇÃO NA CONSTITUIÇÃO BRASILEIRA}

A mediação tem amparo no ordenamento jurídico brasileiro, ou seja, na Constituição Federal de 1988, que representa a vontade do cidadão, visto que em seu preâmbulo $^{3}$, que é o guia de orientação máxima da nação, está assegurado, dentre outras coisas, o bem-estar individual, isto é, o estado de paz que não existe quando há conflito, e a solução pacífica das controvérsias, o que incentiva que outros meios alternativos sejam encontrados (DELGADO, 2003).

Assim, na essência do Estado Democrático Brasileiro está inserido o compromisso com a solução pacífica das controvérsias, um espaço livre de direito não estatal. Portanto, não há nada que inviabilize a mediação na Constituição Federal de 1988, ou que ofenda qualquer dos seus dispositivos.

Os direitos e garantias constitucionais, dispostos no Art. $5^{\circ}$ da Constituição Federal, se aplicam a todo sistema processual, tanto autocomposição como heterocomposição. Assim, a apreciação pelo Judiciário, o juiz natural, o juiz ou tribunal de exceção, o devido

\footnotetext{
3 "Nós, representantes do povo brasileiro, reunidos em Assembléia Nacional Constituinte para instituir um Estado Democrático, destinado a assegurar o exercício dos direitos sociais e individuais, a liberdade, a segurança, o bem-estar, o desenvolvimento, a igualdade e a Justiça como valores supremos de uma sociedade fraterna, pluralista e sem preconceitos, fundada na harmonia social e comprometida, na ordem interna e internacional, com a solução pacífica das controvérsias, promulgamos, sob a proteção de Deus, a seguinte Constituição da República Federativa do Brasil.” (BRASIL, 1998)
} 
processo legal, o contraditório e a ampla defesa estão assegurados, bem como, na mediação (DELGADO, 2003).

A mediação não ofende qualquer dos direitos fundamentais da Constituição brasileira. Um dos direitos fundamentais, descritos no Art. $5^{\circ}$, inciso LIII, é o de que ninguém será processado nem sentenciado senão pela autoridade competente. Na mediação, o mediador não passa a ser um julgador da lide, mas apenas auxilia as partes a chegarem a um consenso em forma ou não de transação, sendo que no caso da transação esta será subscrita pelo mediador, pelos transatores e advogados, constituindo um título executivo extrajudicial.

Outro direito fundamental respeitado pela mediação é o princípio do devido processo legal, que diz respeito à exigência de normas prévias que estabeleçam o acesso ao Judiciário, bem assim a tramitação do processo, seu início e desenvolvimento. De acordo com o Art. $5^{\circ}$, inc. LIV da Constituição Federal, ninguém será privado da liberdade ou de seus bens sem o devido processo legal. Isto, obriga à obediência a um procedimento previamente estabelecido. No caso da mediação, as parte optam por utilizar ou não este mecanismo, observando-se o princípio da voluntariedade da mediação, e, caso não venha a alcançar um acordo poderá ser utilizada a via judicial.

Outros direitos fundamentais como a garantia do contraditório e da ampla defesa, entendida como a efetiva participação das partes litigantes no desenvolver do processo, bem assim a utilização de meios hábeis na defesa, estão protegidos no processo da mediação. Além da preocupação em preservar a participação do advogado, sem ir de encontro com o disposto no Art. 133 da Constituição Federal, não prejudicando as partes.

O mediador não é julgador, não examina o mérito da demanda, não sendo influenciado pelos efeitos desta. Sua função é de estabelecer a paz. Não é uma forma de justiça civil. A mediação já é utilizada na Justiça do Trabalho.

Na mediação as partes têm a possibilidade de dialogar e, assim, tentar um consenso, resolvendo o conflito entre elas. Portanto, não é matéria jurisdicional, não há agressão a qualquer princípio constitucional, preservando-se a totalidade da prestação jurisdicional. 


\subsection{O MEIO AMBIENTE NA CONSTITUIÇÃO BRASILEIRA}

O Meio Ambiente recebe destaque na Constituição Federal de 1988, a primeira a trata da questão ambiental em capítulo específico. O Art. $255^{4}$ da Constituição outorga ao Poder Público e à coletividade o dever de defender e preservar o meio ambiente para as gerações presentes e futuras, e isso só poderá ser alcançado se os recursos naturais forem utilizados de forma sustentável (SILVA, 1997).

Silva (1997:2) conceitua o Meio Ambiente como a "interação do conjunto de elementos naturais, artificiais e culturais que propiciem o desenvolvimento equilibrado da vida em todas as suas formas". Para esse autor a preocupação do Poder Público é preservar, recuperar e revitalizar o meio ambiente, sendo a razão dessa tutela a degradação do meio ambiente que ameaça a qualidade da vida humana.

O Poder Executivo, Legislativo e Judiciário possuem papéis diferenciados na proteção ambiental de acordo com Antunes (2005:56):

Ao Executivo estão afetadas as tarefas de licenciamento e controle das atividades utilizadoras de recursos ambientais. Ao Legislativo compete a elaboração de leis, a fixação de dos orçamentos das agências ambientais e controle das atividades desempenhadas pelo Executivo. Ao Judiciário compete a revisão de todos os atos administrativos praticados pelo Executivo que tenham repercussão sobre o meio ambiente e o controle de constitucionalidade das normas elaboradas por ambos os demais Poderes. Ao Judiciário está reservada, ainda, a importante missão de ser instrumento pelo qual o povo poderá contestar medidas adotadas pelo Executivo e pelo Legislativo que, eventualmente, prejudiquem a qualidade ambiental. É através do Judiciário que os cidadãos interessados poderão contra-arrestar decisões administrativas que não se enquadrem nas normas constitucionais e legais. O Ministério Público, cuja função é eminentemente ativa, tem por tarefa a integral fiscalização dos atos e procedimentos dos Poderes Públicos para, em caso de violação da legalidade, aciona-los judicialmente.

\footnotetext{
${ }^{4}$ Art. 225. Todos têm direito ao meio ambiente ecologicamente equilibrado, bem de uso comum do povo e essencial à sadia qualidade de vida, impondo-se ao Poder Público e à coletividade o dever de defendê-lo e preservá-lo para as presentes e futuras gerações. (BRASIL, 1998)
} 
A sociedade também tem o dever de proteger o meio ambiente, sendo este um direito fundamental do cidadão. A proteção do meio ambiente é pressuposto para o atendimento de outro direito fundamental: o direito à vida (MILARÉ, 2001). O Art. $5^{\circ}$ inciso LXXIII da Constituição Federal dispõe como um dos direitos e garantias fundamentais individuais e coletivas a proposição de ação popular com a finalidade de proteger o meio ambiente.

Além dos artigos já citados, existem outros artigos na Constituição brasileira que trazem referências explícitas ao meio ambiente, como: Art. 91, $§ 1^{\circ}$, inciso III; Art. 129, inciso III; Art. 170, inciso VI, Art. 186, inciso II, dentre outros. Deste modo, pode-se inferir que a mediação não fere o direito fundamental ao meio ambiente sadio, previsto na Lei Maior do país.

\subsection{A GESTÃO AMBIENTAL BRASILEIRA: PRINCÍPIOS E INSTRUMENTOS}

A Política Nacional do Meio Ambiente - PNMA, instituída na Lei $\mathrm{n}^{\mathrm{o}}$ 6.938/81, traz em seu texto instrumentos, objetivos, diretrizes e princípios que conformam as aspirações dos atores sociais no que diz respeito ao uso, controle, proteção e conservação do meio ambiente.

O conceito legal de meio ambiente encontra-se no Art. $3^{\circ}$, inciso I da Lei $\mathrm{n}^{\circ}$ 6.938/81, como: "o conjunto de condições, leis, influências e interações de ordem física, química e biológica, que permite, abriga e rege a vida em todas as suas formas".

Para a doutrina jurídica brasileira o conceito de meio ambiente compreende três aspectos (SILVA, 1997): (i) o ambiente natural constituído pelo ar, solo, água, flora, fauna; (ii) o ambiente cultural integrado pelos objetos artísticos, documentos arqueológicos, sítios históricos etc.; e (iii) o ambiente artificial que compreende as construções do homem, como os edifícios, ruas, praças.

A Política Nacional do Meio Ambiente, apesar de não trazer em seu texto de forma explícita a utilização da mediação nos conflitos socioambientais, enumera alguns instrumentos que foram formulados com base nos princípios que formam e orientam o Direito 
Ambiental. Os princípios de Direito Ambiental, na visão dos autores Machado (2003) e Milaré (2001), são:

(i) poluidor-pagador e usuário-pagador - obriga tanto o poluidor a pagar a poluição causada ou que poderá ser causada por sua intervenção no meio ambiente, quanto o usuário de um recurso natural, a pagar por sua utilização;

(ii) precaução - é a proteção contra a incerteza, ou seja, a necessidade de agir com cautela quando há incerteza científica com relação ao dano que determinada atividade poderá vir causar ao meio ambiente;

(iii) prevenção - é a proteção do risco conhecido, impondo ações que evitem ou minimizem o dano;

(iv) cooperação - impõe a cooperação entre os povos no âmbito internacional, e a cooperação entre os Entes da federação e entre o Poder Público e a sociedade no âmbito interno, visando alcançar o desenvolvimento sustentável;

(v) informação - todos têm direito a ter acesso adequado às informações relativas ao meio ambiente, exceto as que envolvam segredo industrial;

(vi) participação - este princípio é indissociável do princípio da informação e da cooperação. É a atuação da sociedade na formulação e execução da política ambiental, visto que também a coletividade tem obrigação de cuidar e proteger o meio ambiente;

(vii) obrigatoriedade da intervenção do Poder Público - a gestão do meio ambiente é tarefa do Estado que possui aparato institucional para planificar, administrar e controlar a utilização dos recursos naturais. 
De todos os princípios que norteiam o direito ambiental, o da participação e conseqüentemente, da informação e cooperação servem de suporte para a utilização da mediação na resolução de conflitos socioambientais..

Diversos acordos internacionais, dos quais o Brasil é signatário, tratam da participação pública, tais como: Agenda 21, Declaração do Rio, Convenção da Bio Diversidade e o Protocolo de Kioto. Destacamos, dentre eles, o princípio 10 da Declaração do Rio de Janeiro (MINISTÉRIO DO MEIO AMBIENTE, 2005):

A melhor maneira de tratar as questões ambientais é assegurar a participação, no nível apropriado, de todos os cidadãos interessados. No nível nacional, cada indivíduo terá acesso adequado às informações relativas ao meio ambiente de que disponham as autoridades públicas, inclusive informações acerca de materiais e atividades perigosas em suas comunidades, bem como a oportunidade de participar dos processos decisórios. Os Estados irão facilitar e estimular a conscientização e a participação popular, colocando as informações à disposição de todos. Será proporcionado o acesso efetivo a mecanismos judiciais e administrativos, inclusive no que se refere à compensação e reparação de danos.

O princípio 10 da Declaração do Rio de Janeiro dispõe ainda sobre a necessidade de proporcionar à sociedade mecanismos judiciais e administrativos, e porque não extrajudiciais na resolução de questões ambientais. Todavia, na gestão ambiental brasileira não se tem utilizado a ferramenta mediação para viabilizar a solução consensual dos conflitos de interesses ambientais.

Na Política Nacional do Meio Ambiente estão previstos instrumentos, atos e medidas que possibilita o Poder Público executar a política ambiental, tendo em vista a preservação, melhoria e recuperação do meio ambiente e do equilíbrio ecológico. Os instrumentos estão enumerados no Art. $9^{\circ}$ da Lei $n^{\circ}$ 6.938/81:

\footnotetext{
I - o estabelecimento de padrões de qualidade ambiental;

II - o zoneamento ambiental;

III - a avaliação de impactos ambientais;
} 
IV - o licenciamento e a revisão de atividades efetiva ou potencialmente poluidoras;

V - os incentivos à produção e instalação de equipamentos e a criação ou absorção de tecnologia, voltados para a melhoria da qualidade ambiental;

VI - a criação de espaços territoriais especialmente protegidos pelo Poder Público federal, estadual e municipal, tais como áreas de proteção ambiental, de relevante interesse ecológico e reservas extrativistas;

VII - o sistema nacional de informações sobre o meio ambiente;

VIII - o Cadastro Técnico Federal de Atividades e Instrumento de Defesa Ambiental;

IX - as penalidades disciplinares ou compensatórias não cumprimento das medidas necessárias à preservação ou correção da degradação ambiental;

X - a instituição do Relatório de Qualidade do Meio Ambiente, a ser divulgado anualmente pelo Instituto Brasileiro do Meio Ambiente e Recursos Naturais Renováveis - IBAMA;

XI - a garantia da prestação de informações relativas ao Meio Ambiente, obrigando-se o Poder Público a produzi-las, quando inexistentes;

XII - o Cadastro Técnico Federal de atividades potencialmente poluidoras e/ou utilizadoras dos recursos ambientais.

A gestão do meio ambiente se apóia nesses instrumentos e em instrumentos jurídicos, como a ação popular, a ação civil pública e a ação penal pública.

Observa-se que o princípio da participação permeia todos esses instrumentos da política ambiental brasileira, principalmente o licenciamento ambiental, visto que a participação pública aumenta o envolvimento, a responsabilidade da Administração Pública, a qualidade da tomada de decisão, além da credibilidade e da confiança na decisão.

No processo de tomada de decisão há interesses distintos colocados; há conflito, ou seja, divergência de interesses, que deve ser gerenciado a fim de evitar que sua escalada possa levar a uma solução não sustentável e impraticável. Esta é uma arena que favorece o uso da mediação como forma de participação e pacificação social. 
A participação do público no processo de gestão ambiental está assegurada no processo de licenciamento, quando da realização de Audiência Pública, momento em que a população é informada sobre o projeto e seus impactos ambientais; dirimidas duvidas e recolhidas as criticas e sugestões. Nessa ocasião o empreendedor poderá comprometer-se a executar ações estabelecidas nos programas apresentados nos estudos ambientais.

Os fundamentos da Audiência Pública são: o princípio da participação e da informação, núcleos da cidadania, preconizados na Declaração do Rio de Janeiro. Eles garantem que o processo de licenciamento ambiental se dê de forma participativa e transparente, e que a decisão do órgão ambiental licenciador seja motivada não só em critérios técnico-científicos, mas também nas considerações da coletividade, enquanto titular dos bens ambientais em discussão (CAVEDON; DOMINGOS, 2004).

Derani (Apud CAVEDON; DOMINGOS, 2004:3799) destaca que a participação da sociedade nos "programas decisórios, de planejamento e licença de atividades geradoras de grande impacto no ambiente é um avanço no sentido da democratização da realização de políticas para a conservação ambiental ou realização de estratégias de sustentabilidade".

A Audiência Pública é um meio para o cumprimento da função ambiental compartilhada entre Estado e sociedade preconizada no Art. 225 da Constituição Brasileira. O órgão responsável pelo licenciamento compartilha com a sociedade o seu poder decisório, como meio de legitimação da decisão pública ambiental. É espaço para exercício da cidadania, que antecede o momento de tomada de decisão sobre a utilização de bens ambientais ou danos a ser provocado ao meio ambiente. A natureza do bem tutelado, o meio ambiente e dos conflitos exigem procedimento democráticos de gestão e decisão (CAVEDON; DOMINGOS, 2004).

Deve-se salientar, que conflitos socioambientais podem ser revelados numa Audiência Pública, e nesse caso a mediação pode ser indicada como meio eficaz para administrar e resolver os conflitos. Todavia, os conflitos socioambientais aparecem em todos os instrumentos utilizados na política ambiental, bem assim fora deles. 


\subsection{O ANTEPROJETO QUE INSTITUCIONALIZA A MEDIAÇÃO NO PROCESSO CIVIL}

Como mencionado no início deste capítulo, existe um Anteprojeto ${ }^{5}$ elaborado por uma comissão coordenada por Ada Pellegrini Grinover, que tem por finalidade institucionalizar o uso da mediação, prévia e incidental, no processo civil. Esse Anteprojeto cria condições para que as lides que chegam no judiciário possam ser solucionadas não somente pelo juiz, mas pelas próprias partes, uma vez que a aplicação da lei não é a única forma de resolução de conflitos.

O objetivo do Anteprojeto não é aliviar a carga do judiciário, mas: (i) facilitar o acesso a um procedimento mais efetivo; (ii) proporcionar mais tutela e menor custo; (iii) diversificar formas de resolução de conflito; (iv) desjusticializar o sistema; (v) instaurar a cultura do diálogo; (vi) abandonar a cultura do litígio.

$\mathrm{Na}$ visão de Dias (2003), da forma como prevista no Anteprojeto, a mediação visa dar maior rapidez, confidencialidade (mediador não anota, não se produz prova), informalidade, flexibilidade, economia de custo e solução mais justa à resolução do conflito.

O Anteprojeto está dividido em três capítulos: modalidades de mediação paraprocessual, da mediação (prévia e incidental), e dos mediadores. Para este trabalho interessa o último capítulo referente aos mediadores.

O mediador, como previsto no anteprojeto de lei, será um advogado, que poderá sugerir as partes uma proposta de acordo, dando roupagem jurídica à mesma, o que demonstra a adoção da corrente acordista, chegando muito próximo da conciliação, e não da corrente transformadora.

Esse advogado será credenciado pela $\mathrm{OAB}$, tendo pelo menos dois anos de experiência (Art. 10). A OAB ficará encarregada da formação e seleção dos advogados (Art. $\left.10, \S 1^{\circ}\right)$, porém, serão dispensados do curso de capacitação os conciliadores dos Juizados Especiais e os conciliadores judiciais (Art. 10, $\S 2^{\circ}$ ).

\footnotetext{
${ }^{5}$ Ver Anexo B.
} 
Verifica-se que a indicação do advogado como mediador não está de acordo com o suporte teórico da mediação, pois o mediador precisa ser um profissional imparcial e neutro, capacitado para criar um ambiente de diálogo entre as partes. Não é, portanto, admissível que somente o advogado possa atuar como mediador excluindo toda uma gama de profissionais de outras especialidades.

Também não é verdadeira a presunção de que a atividade do conciliador o capacite para exercício da função de mediador, pois o conciliador trabalha na presença do juiz, trata de causas até o valor máximo de quarenta vezes o salário mínimo e não tem por objetivo a transformação do conflito, o emponderamento, ou a validação dos sentimentos das partes (OLIVEIRA, 2002).

De acordo com o Art. 16 do Anteprojeto, o mediador não pode atuar nas causas de impedimento do Art. 134 do Código de Processo Civil, devendo ser sorteado novo mediador. Nota-se que esse artigo algumas situações são enumeradas que impedem ao juiz de exercer suas funções no processo contencioso ou voluntário. Todavia, não foram acrescentadas as causas de suspensão do Art. 135, também do Código de Processo Civil, que devem impedir a atuação do mediador.

Os casos de impedimentos e suspensão previstos nos artigos 134 e 135 do Código de Processo Civil, também deverão valer para o mediador de conflitos socioambientais.

Outro ponto apresentado no Anteprojeto está no Art. 19. O mediador fará jus a honorários, quando houver a transação, ou seja, o consenso. E caso haja co-mediação, esse honorário fica dividido entre os mediadores. Entretanto, quando as partes não alcancem a transação, o mediador fica sem qualquer tipo de remuneração.

Tal condição além de injusta, visto que o mediador trabalhou criativamente no intuito de auxiliar as partes a transformarem o conflito em consenso. Também, poderá levar o mediador a exercer um papel diferente do previsto, como, por exemplo, forçar às partes a chegarem a um acordo, sem que estes tenham compreendido a situação de conflito. 
Todos os pontos acima estão relacionados à figura do mediador, o que é importante, para o caso do governo decidir institucionalizar a mediação de conflitos socioambientais.

\subsection{A INSTITUCIONALIZAÇÃO DA MEDIAÇÃO PARA RESOLUÇÃO DE CONFLITOS SOCIOAMBIENTAIS}

Em entrevista dada pela Ministra do Meio Ambiente - Marina Silva, à Folha de São Paulo, esta revelou a intenção de criar uma Câmara de Mediação Ambiental (SATO, 2005). Entretanto, no discurso da Ministra não há qualquer indicação de como esta câmara será criada, se por meio de lei, de resolução, de portaria, bem assim se a câmara será federal, estadual ou municipal.

Partindo do nome dado ao local onde serão mediados os conflitos socioambientais, ou seja, uma Câmara Técnica de Mediação Ambiental, conforme consta da referida entrevista, nota-se que a mesma nomenclatura é utilizada para se referir a uma das composições existentes nos conselhos de meio ambiente. Assim, para proceder uma análise da possibilidade de materialização da sugestão feita pela Ministra tomou-se como exemplo, o Conselho Nacional de Meio Ambiente - CONAMA, um colegiado representativo de órgãos federais, estaduais e municipais, setor empresarial e sociedade civil.

O CONAMA é um órgão consultivo e deliberativo do SISNAMA, composto por Plenário, Câmaras Técnicas, Grupos de Trabalhos e Grupos de Assessores, conforme o disposto na Portaria $n^{\circ}$ 168/2005. Os artigos 22 e 23 dessa portaria dispõem sobre a criação de onze câmaras técnicas:

Art. 22. As Câmaras Técnicas são instâncias encarregadas de desenvolver, examinar e relatar ao Plenário as matérias de sua competência.

Parágrafo único. Na composição das Câmaras Técnicas, deverão ser consideradas a natureza técnica da matéria de sua competência e a finalidade dos órgãos ou entidades nela representadas.

Art. 23. As Câmaras Técnicas de que trata este artigo terão as seguintes denominações:

I - Biodiversidade, Fauna e Recursos Pesqueiros; 
II - Florestas e Atividades Agrossilvopastoris;

III - Unidades de Conservação e demais Áreas Protegidas;

IV - Gestão Territorial e Biomas;

V - Controle e Qualidade Ambiental;

VI - Saúde, Saneamento Ambiental e Gestão de Resíduos;

VII - Atividades Minerárias, Energéticas e de Infra-Estrutura;

VIII - Economia e Meio Ambiente;

IX - Educação Ambiental;

$\mathrm{X}$ - Assuntos Internacionais; e

XI - Assuntos Jurídicos.

$\S 1^{\mathrm{o}}$ Poderão ser convidados a participar das reuniões da Câmara Técnica, representantes de segmentos interessados nas matérias e colaboradores, a critério do Presidente de referida Câmara.

$\S 2^{\circ}$ As Câmaras Técnicas serão constituídas por até sete conselheiros titulares e/ou suplentes, definidos pelo Plenário, ou ainda por representantes por eles indicados formalmente à Secretaria-Executiva, com direito à voz e ao voto.

$\S 3^{\circ}$ Os membros das Câmaras Técnicas terão mandato de dois anos, renovável uma única vez, por igual período.

$\S 4^{\circ}$ Cada entidade ou órgão representado somente poderá participar, simultaneamente, de até duas Câmaras Técnicas, respeitado o princípio de que cada segmento, órgãos federais, estaduais, municipais, empresariais e da sociedade civil, deverá estar representado em todas as Câmaras Técnicas.

$\S 5^{\circ}$ A Secretaria-Executiva requisitará às respectivas Secretarias do Ministério do Meio Ambiente, ao IBAMA e à ANA a indicação de representantes para dar suporte aos trabalhos das Câmaras Técnicas.

Da mesma forma, os conselhos de meio ambiente estaduais e municipais são órgão colegiados que podem criar câmaras técnicas de acordo com a necessidade observada.

Numa análise superficial da composição do Conselho de Meio Ambiente, pode-se inferir que nada impede que uma câmara técnica em mediação seja criada em cada conselho ambiental com a finalidade de mediar conflitos socioambientais, não somente para o 
licenciamento ambiental, mas em todos instrumentos da gestão ambiental e em todos os conflitos socioambientais cuja solução dependa de diálogo entre os vários atores envolvidos.

Entretanto, todas as câmaras técnicas tanto do CONAMA quanto de outros conselhos devem examinar e relatar na Plenária as matérias de sua competência. No caso de uma Câmara de Mediação, os conflitos administrados e resolvidos nessa câmara, não poderão ser discutidos, nem relatados na Plenária do conselho, pois estes devem ser resolvidos pelas partes com o auxílio do mediador, inclusive sua divulgação só poderá ocorrer se acordado entre as partes envolvidas.

Outro fato importante é a composição das câmaras. Apesar da composição multi-setorial, os membros dos conselhos federal, estadual e municipal são os mesmos integrantes das câmaras técnicas. Todavia, para o perfeito funcionamento de uma câmara de mediação faz-se necessária a seleção de mediadores capacitados, imparciais e neutros, que poderão não estar no rol dos membros dos conselhos ambientais. Além disso, deve predominar a informalidade e a oralidade, que são princípios que norteia o processo de mediação; o que fere as normas do conselho, em que todos os atos e debates devem ser registrados em Ata de Reunião.

Já no processo de licenciamento ambiental a mediação somente poderia ser inserida na fase de realização da Audiência Pública. Isso limitaria o uso de um instrumento capaz de reunir os diversos atores sociais em conflito para questões específicas. A mediação pode e deve ser utilizada como instrumento capaz de abrir o diálogo e suscitar soluções criativas não somente sobre problemas relacionados ao processo de licenciamento ambiental, mas a todos os instrumentos de gestão ambiental, e fora deles.

Desse modo, pode-se inferir que a criação de Câmaras de Mediação Ambiental no âmbito dos conselhos ambientais - federal, estadual e municipal -, por meio de Portaria Interna desses conselhos, seria uma solução que precisa ser melhor estudada. Ademais, apesar dos conselhos serem formados por vários setores, de serem fórum de discussão, tendo caráter deliberativo, consultivo e normativo; não comportam toda a dimensão teórica e os princípios relativos a mediação. 
Salienta-se, com base no que foi colocado nos capítulos 1 e 2 deste trabalho, que uma Câmara de Mediação Ambiental precisa estar aberta às partes envolvidas no conflito socioambiental, para que ela possa iniciar um processo de mediação, dentro ou fora do licenciamento ambiental, ou mesmo para obter algum tipo de esclarecimento sobre determinado problema. Além do mais, em uma sessão de mediação, o mediador treinado deverá buscar, por meio do diálogo, promover a igualdade de condições das partes, a comunicação real, clara e honesta, possibilitando um debate construtivo que possa alcançar a solução pacífica do conflito.

Continuando a análise do discurso da ministra, verifica-se a indicação da Advocacia Geral da União (AGU) como possível mediadora nessas câmaras, mas a AGU, de acordo com a Constituição Federal, não pode ser indicada para tal, uma vez que não é função da AGU atuar como mediadora na resolução de conflitos socioambientais:

Art. 131. A Advocacia-Geral da União é a instituição que, diretamente ou através de órgão vinculado, representa a União, judicial e extrajudicialmente, cabendo-lhe, nos termos da lei complementar que dispuser sobre sua organização e funcionamento, as atividades de consultoria e assessoramento jurídico do Poder Executivo.

Art. 132. Os Procuradores dos Estados e do Distrito Federal exercerão a representação judicial e a consultoria jurídica das respectivas unidades federadas, organizados em carreira, na qual o ingresso dependerá de concurso público de provas e títulos, observado o disposto no art. 135.

Da mesma forma a Lei Complementar $n^{\circ}$ 073/93 que institui a lei orgânica da AGU não dispõe sobre a possibilidade de criação de câmaras ou da atuação do AdvogadoGeral da União como mediador de conflitos, apesar do Art. $4^{\circ}$ inciso VI dispor sobre a possibilidade deste "desistir, transigir, acordar e firmar compromisso nas ações de interesse da União".

No caso da mediação a AGU pode representar a União, mas não poderia atuar como mediadora. Nesse sentido, a sugestão da ministra não encontra qualquer respaldo jurídico. Além disso, não se pode reservar a tarefa de mediação especificamente aos profissionais de direito, excluindo a priori profissionais de outras especialidades científicas, 
ou mesmo impedir a escolha de mediadores segundo a natureza da matéria e a sua habilitação para o caso. 


\title{
4 CASOS DE MEDIAÇÃO DE CONFLITOS SOCIOAMBIENTAIS
}

\begin{abstract}
Partindo da base teórica do conflito socioambiental e da mediação, abordados nos Capítulos 1 e 2 deste trabalho, analisou-se três casos que ilustram a possibilidade de utilização da mediação nos conflitos socioambientais: (i) o caso do Projeto de Assentamento Margarida Alves em Rondônia (OLIVEIRA; BURSZTYN, 2005); (ii) o do uso do fogo por agricultores familiares em Roraima (ALMEIDA, 2005); e (iii) o conflito socioambiental deflagrado no setor habitacional Grande Colorado na Área de Proteção Ambiental de Cafuringa - Distrito Federal (LARANJEIRA; MOURÃO, 2005).
\end{abstract}

No primeiro capítulo analisou-se o conflito socioambiental, em que foi possível verificar que muitas vezes nesse tipo de conflito há ausência de direitos legais claros; as partes envolvidas normalmente desejam preservar suas relações, sendo enfatizado o trato futuro; além do desejo das partes de controlarem o processo de resolução do conflito, evitando a via judicial, dentro outros aspectos.

No segundo capítulo aprofundou-se estudo sobre a base teórica da mediação, em que foi enfatizado o suporte necessário para a utilização desse mecanismo de resolução alternativo de disputas com vista a administração e resolução consensual dos conflitos socioambientais.

Usualmente, segundo Cooley (2001), as partes em conflito optam pela utilização da mediação como mecanismo de resolução de conflitos, pelos seguintes motivos: (i) o desejo de preservar relações continuadas; (ii) a ênfase no trato futuro; (iii) a necessidade de evitar decisões que envolvam ganhar ou perder absolutamente; (iv) o desejo das partes de terem controle sobre o processo; (v) a disputa tem múltiplas partes e questões; (vi) a ausência de direitos legais claros.

Os casos de mediação ambiental a serem apresentados a seguir, apesar de empíricos, isto é, não seguem o aporte teórico da mediação estudado neste trabalho, ilustram a possibilidade da utilização desse mecanismo na gestão ambiental brasileira. 
Primeiro caso: Projeto de Assentamento (PA) Margarida Alves em Rondônia (OLIVEIRA; BURSZTYN, 2005). Este conflito envolve diferentes atores na posse e/ou uso da Reserva Legal em Bloco, um projeto de assentamento do INCRA em Rondônia, que não possui amparo legal. Não houve qualquer tipo de fiscalização pelo INCRA, que não dispõe de estrutura de fiscalização; nem pelo IBAMA, que alegou que a área não é uma reserva federal criada pelo órgão.

O PA Margarida Alves foi criado em novembro de 1997 e abrange uma área de 11.990 hectares no município de Nova União, em Rondônia. Nessa área a vegetação predominante é a floresta equatorial subpernifólia. O conflito envolve a disputa pelo domínio e pela gestão dessa floresta. Foram assentadas famílias no local, mas há constantes invasões de madeireiros e grileiros que possuem apoio político na região de Ouro Preto do Oeste. Já foram desmatados 400 hectares da floresta nativa na região próxima ao assentamento, afetando as nascentes e os cursos d'água vitais para o abastecimento das famílias assentadas. Quase toda a madeira foi retirada ilegalmente.

Os invasores acreditam que a reserva não é uma Unidade de Conservação e que não há proprietários, visto que não há registro nos cartórios e o órgão ambiental não dispõe de documentação sobre a área. O INCRA ajuizou ação de reintegração de posse em desfavor dos invasores, mas os invasores não obedeceram à determinação judicial de desocupação do local. Em função disso, a Associação dos Produtores Alternativos assumiu a liderança da negociação com os invasores, com o objetivo de concretizar a desocupação do local, o que só ocorreu em novembro de 2002. Em maio de 2003, os assentados ganharam o reconhecimento da área, e com isso, conseguiram aprovar o projeto de manejo comunitário pelo Fundo Nacional do Meio Ambiente.

Pelo relato do processo e com base nas informações de conflitos abordadas no capítulo 1 deste trabalho, pode-se inferir que o conflito na PA Margarida Alves é real (percebido com exatidão), há falta ou má informação (conflito de natureza de dados), há situação de escassez (conflito de natureza de interesses) e a atuação dos atores é interpessoal.

Esse conflito socioambiental gira em torno do controle sobre os recursos naturais, ou seja, da floresta equatorial subpernifólia; e envolve vários atores: a Associação dos Produtores Alternativos; o Movimento dos Sem-Terra (MST); os invasores; o INCRA e o 
Ibama. Os atores - INCRA e MMA - procuraram resolver a questão da posse e/ou uso da Reserva Legal em Bloco, retirando os invasores e aprovando o Projeto de Manejo Comunitário, que possibilitou o reconhecimento da área e o seu uso de forma sustentável.

A ferramenta mediação foi utilizada nesse caso, pela Associação dos Produtores Alternativos, que atuou como mediadora do conflito. Inicialmente o INCRA ajuizou ação de reintegração de posse em desfavor dos invasores, para a desocupação do local, mas eles não obedeceram à ordem judicial. A Associação dos Produtores Alternativos assumiu a liderança da negociação com os invasores, e em novembro de 2002 conseguindo a desocupação do local. O MMA atuou no processo aportando recursos financeiros e pessoal técnico para a elaboração do projeto de manejo comunitário e reconhecimento da área.

O segundo caso: uso do fogo por agricultores familiares em Roraima (ALMEIDA, 2005). O estado de Roraima pertence à região da Amazônia Legal, e apresenta a maior variedade de fisionomias vegetais dos estados amazônicos. O conflito ocorre em torno dos impactos gerados pela "ação humana, pela degradação dos ecossistemas pelo esgotamento dos recursos naturais". O foco central do conflito é as queimadas feitas pelos agricultores, sem qualquer medida preventiva e estrutural, que seja capaz de evitar que o mesmo se propague pela floresta, causando grande degradação ambiental.

O solo dessa região possui baixa fertilidade natural. O uso de fogo para o desmatamento inicialmente beneficia o solo, pois incorpora nutrientes da biomassa na forma de cinzas ao solo, porém, com a prática anual do uso do fogo, ocorre a substituição da vegetação original por gramíneas e ervas. As queimadas provocadas e acidentais acabam por ocasionar o aumento do nível de estresse hídrico na área, que aliada à elevação de temperatura e a longa estiagem aumentam o risco de incêndios florestais. Além disso, a fumaça prejudica a saúde da população e o fogo degrada recursos ambientais importantes, inclusive o ar.

Apesar do fogo ser a principal ferramenta utilizada pelos agricultores para o desmatamento e limpeza de áreas, pelo seu menor custo e benefício inicial ao solo, não há uma política específica do governo, que possa levar o abandono dessa prática. Há críticas de ambientalistas e da população, porém faltam diálogo e compreensão de seus papéis na administração e resolução do conflito. 
Pode-se classificar esse conflito como real (percebido com exatidão). Há também falta ou má informação (conflito de natureza de dados), há situação de (conflito de interesses (em função da escassez de um recurso natural), e de relacionamentos. A atuação dos atores é interpessoal, destacando-se a presença de instituições governamentais como o Governo do Estado e o IBAMA; instituições não-governamentais como a Associação de Agricultores e a Pastoral da Juventude; organismos multilaterais internacionais como o USAID e o Banco Mundial; e os agricultores, índios, fazendeiros, trabalhadores rurais, dentre outros.

Esse conflito socioambiental gira em torno dos impactos ambientais e sociais gerados tanto pela ação humana quanto pela própria natureza. Ou seja, o uso do fogo para desmatamento pelos agricultores ou incêndios naturais que ocorrem nos períodos de estiagem prolongada.

Nesse conflito há uma tendência para que as partes utilizem o mecanismo de resolução de conflitos, chamado de negociação direta, mas a mediação é utilizada quando o Projeto Proteger II mobilizou a sociedade civil em torno da questão do uso do fogo e gerou motivação para uma mudança de atitude dos usuários do fogo. Do mesmo modo, quando os poucos processos de articulação entre a sociedade civil e as instituições governamentais geraram acordos como o "calendário de proibição" de queimadas que avançou para um "calendário de queima".

Nesse caso foram apontadas as seguintes dificuldades na busca da administração e solução pacífica desse conflito: não há parcerias envolvendo os atores do conflito; há dificuldade de diálogo entre os atores; há falta de compreensão dos papéis de cada ator na administração e resolução do conflito; não há políticas públicas de compensação que viabilizem a redução ou abandono do uso do fogo.

O terceiro caso: o conflito socioambiental deflagrado no setor habitacional Grande Colorado na Área de Proteção Ambiental de Cafuringa - Distrito Federal (LARANJEIRA; MOURÃO, 2005), bairro de classe média e média-alta, composto por dez condomínios e um comércio local. A ocupação do local começou no final dos anos 80 , mas a situação ambiental agravou-se com a falta de licenciamento ambiental e o rápido adensamento populacional após o ano 2000. 
Havia um conflito socioambiental potencial desde o início da ocupação do local. Entretanto, o conflito somente passou a ser real em outubro de 2003, após o IBAMA começar a fiscalizar a área e se manifestar contrário ao licenciamento ambiental, aplicando multas e embargos aos moradores em janeiro de 2002, após a criação da APA de Cafuringa.

O Setor Habitacional do Grande Colorado, apesar de ser rico em nascentes, apresenta vários problemas, como: o uso de poços profundos para o consumo de água; falta zoneamento ambiental, não é feita coleta de esgoto; os moradores utilizam fossas sépticas e sumidouros; a coleta de lixo é precária; a mata nativa foi desmatada.

A deflagração do conflito ocorreu em outubro de 2003, quando o IBAMA, por imposição do Ministério Público, iniciou o processo de fiscalização no local, aplicando sanções aos moradores. O foco central do conflito é a ocupação irregular de uma área, que ocorreu em função de busca de melhor qualidade de vida pelos indivíduos, ocupação essa, que por sua vez, compromete a sustentabilidade ambiental da área que comporta importantes nascentes. A disputa, nesse caso, se configura entre o interesse coletivo da sociedade como um todo (região de nascente) e o privado (moradias particulares).

A situação ambiental da área e sua ocupação para construção de condomínio residencial indicam que havia um conflito potencial desde o início da ocupação do Setor Habitacional do Grande Colorado. No entanto, só a partir da aplicação de multas pelo IBAMA o conflito passou a ser declarado, tornando-se real, e possibilitando a identificação de seu foco, de seus atores, bem assim da mobilização em busca de uma solução pacífica.

Esse conflito socioambiental gira em torno dos impactos ambientais e sociais gerados pela ocupação humana do meio natural, podendo ser classificado como: real, de falta ou má informação (conflito de natureza de dados), de situação de interesse (conflito de natureza de escassez), e de relacionamentos. Os atores envolvidos no conflito são: os moradores, o Ibama, o Ministério Público e o Governo do Distrito Federal. Porém este último não participou de qualquer tipo de negociação, pois ao não rxercer suas atribuições, o Ministério Público convocou o Ibama para atuar supletivamente no caso, conforme previsto na legislação ambiental. 
O Setor Habitacional está localizado em uma Área de Proteção Ambiental (APA), que é um espaço coletivo. Nesse setor, cada morador passou a defender seus interesses de forma individual. Assim, verificou-se que houve mudança na forma de atuação dos moradores: do individual para o coletivo, dos padrões de consumo, das relações sociais, das partes para o todo.

$\mathrm{Na}$ mediação desse conflito participaram os moradores, o Ibama e o Ministério Público, ficando excluído o Governo do Distrito Federal em função de sua omissão no caso. Existem vários desafios a serem superados, como: trazer o governo do DF para o processo de negociação e a organização dos moradores de forma a agirem em grupo para a busca de uma resolução que beneficie a todos.

Os exemplos relatados servem para ilustrar a complexidade e relevância dos conflitos socioambientais e a possibilidade de uso da mediação, nos moldes apresentados neste trabalho. Entretanto, apesar de reconhecer que não há necessidade de um espaço formal para que se promova esse tipo de negociação, pode-se verificar que a sua inexistência criação de uma estrutura institucional que promova o uso desse mecanismo de resolução também dificulta a adoção dessa ferramenta pelas partes envolvidas no conflito.

O que se pode inferir é que a ocorrência de inúmeros conflitos socioambientais demandam um local adequado para as sessões de mediação, um rol de mediadores capacitados para lidarem com tais conflitos e defina os princípios, critérios, técnicas que servirão de base no processo de mediação.

O Brasil enfrenta diariamente vários problemas em torno de conflitos ligados ao uso, acesso e aproveitamento dos recursos naturais. Em muitos casos, pode-se identificar as seguintes situações: gestão dos recursos ambientais limitados, instituições debilitadas, meios escassos, dinâmicas sociais e econômicas cada vez mais complexas, falta de diálogo entre os atores envolvidos nos conflitos socioambientais.

Entende-se, portanto, que a administração de conflitos socioambientais, oferecem oportunidades para analisar e transformar relações de uso, acesso e aproveitamento dos recursos naturais. Entretanto, em muitos casos o Estado não tem meios para tratar de situações de conflitos socioambientais que requerem tempo e recursos para serem atendidas. 
Na busca de resolução dos conflitos socioambientais o meio mais utilizado é a via judicial, onde se estabelece um processo que se sustenta em certos princípios a partir dos quais se persegue a resolução desses conflitos, e que possui as seguintes características: busca do restabelecimento da ordem social a partir do cumprimento das normas, formalidade, adversariedade, limitação do papel das partes, e os mecanismos fortes de imposição da resolução.

Há ainda uma série de mecanismos alternativos, entre eles a mediação, que é um instrumento de resolução de disputas que permite vislumbrar soluções criativas mais adequadas, possibilitando o diálogo entre todos os atores envolvidos, proporcionando a conservação e melhora da inter-relação existente. Também permite a prevenção de futuras disputas, e leva à conscientização ecológica dos atores que deverão firmar compromissos ao longo do procedimento. 


\section{CONCLUSÃO}

Todos os conflitos socioambientais têm haver em alguma medida com a gestão ambiental dos recursos, ou seja, com a forma que o homem se apropria dos recursos ambientais e como o Estado normatiza e administra o uso e aproveitamento de tais recursos.

A natureza e a magnitude da problemática sociambiental, unido aos fortes problemas de natureza institucional tem transcendido a capacidade dos órgãos gestores do meio ambiente resolver e estabelecer um diálogo com os diferentes atores envolvidos no conflito, no sentido de viabilizar uma solução consensual e participativa.

A mediação representa um meio consensual que pode ser empregado na resolução de conflitos socioambientais no qual a decisão será tomada pelas partes envolvidas. O mediador deverá facilitar o diálogo e a comunicação, administrando o conflito de modo positivo, possibilitando a sua transformação, em solução pacífica e consensual, além de prevenir e educar para o enfrentamento de novos conflitos.

$\mathrm{Na}$ mediação, a comunicação e o diálogo entre as partes servem de instrumento de conscientização dos direitos e deveres das partes, pois por meio da administração participativa do conflito os atores podem estabelecer uma relação mais harmônica.

Salienta-se que a mediação ambiental não contraria qualquer dispositivo constitucional ou infraconstitucional, e os princípios da participação, da informação e da cooperação que norteiam a política ambiental, também fundamentam o processo de mediação.

Quanto à criação de Câmaras de Mediação Ambiental como preconizada pela Ministra do Meio Ambiente, observou-se que da forma como dita não encontra o devido respaldo legal, visto que as câmaras técnicas que compõem os conselhos de meio ambiente federal, estadual e municipal não comportam toda a dimensão teórica e os princípios relativos à mediação, como o princípio da confidencialidade, da oralidade e do empoderamento. 
Ademais, o Advogado-Geral da União não poderia atuar como mediador, devido às determinações constitucionais sobre a carreira. Da mesma forma, os integrantes das câmaras técnicas dos conselhos ambientais, da forma como estão previstas suas atribuições também não podem atuar como mediadores.

Na realidade, qualquer profissional poderá atuar como mediador, desde que preparado para tal função, que saiba agir de forma imparcial e neutra no conflito e utilizar as técnicas de negociação disponíveis. Ao mediador cabe particularmente, propiciar a comunicação entre as partes, impedir diálogos improdutivos, bem assim auxiliar as partes a realizarem escolhas voluntárias e conscientes.

Salienta-se que a mediação poderá ser aplicada a todos os tipos de conflitos socioambientais, não apenas aqueles manifestados no âmbito do licenciamento ambiental, de modo que os diferentes atores da sociedade possam utilizar as vantagens oferecidas por esse mecanismo de resolução de alternativa de disputas.

Assim, caberia aos formuladores da política ambiental estudar a viabilidade de institucionalizar a mediação ambiental, como um instrumento de apoio às diversas ações de gestão ambiental. Com isso o Estado estará propiciando um espaço para que as partes em conflitos iniciem um processo de discussão, de aproximação, de harmonização de interesses. Tal procedimento educa as partes a buscarem soluções consensuais para o conflito apresentado.

Além disso, esse fórum de discussão, propiciaria às partes envolvidas, em qualquer conflito socioambiental, pleno acesso à informação, igualando as condições que possibilitem o emprego do diálogo, facilitado pelo mediador, que seria um profissional habilitado para tal função. 


\section{REFERÊNCIAS BIBLIOGRÁFICAS}

ALMEIDA, Júlio César Magalhães de. Uso do fogo por agricultores familiares em Roraima: conflitos e intervenções socioambientais. In: THEODORO, Suzi Huff (Org.). Mediação de Conflitos Socioambientais, Rio de Janeiro: Editora Garamond Ltda, 2005.

ANTUNES, Paulo de Bessa. Direito Ambiental. 7ª ed. Rio de Janeiro: Editora Lúmen Juris, 2005

AZEVEDO, André Gomma. Arbitragem, Mediação e Negociação. Notas de aula ministrada na UnB, Brasília, 01 jun./27 jun. 2002.

AZEVEDO, André Gomma de; LIEBMAN, Carol B. O Processo de Mediação: Teoria e Técnicas. Brasília, 06 ago/27 out. 2001.

BACELLAR, Roberto Portugal. A mediação no contexto dos modelos consensuais de resolução de conflitos. Revista Cidadania e Justiça - O Direito no Século XXI, Rio de Janeiro: Associação dos Magistrados Brasileiros, ano 4, n. 8, $1^{\circ}$ semestre de 2000.

BRASIL. Código Civl. Lei nº 10.406, de 10.01.2002.

BRASIL. Código de Processo Civil. Lei no 5.869, de 11.01.1973.

BRASIL. Consolidação das Leis do Trabalho. São Paulo: LTr, 2004.

BRASIL. Constituição Federal. Promulgada em 05.10.1988.

BRASIL. Política Nacional do Meio Ambiente. Lei nº 6.938, de 31.08.1981.

BRASIL. Lei Complementar no 73, de 10.02.1993.

BRASIL. Portaria ${ }^{\circ} 168$ do CONAMA, de 10.06.2005.

CADEDON, Fernanda de Salles; DOMINGOS, Silva. A Audiência Pública como instrumento de participação pública e acesso à informação nos processos decisórios de licenciamento ambiental: espaço de cidadania ambiental? Revista de Direitos Difusos, São Paulo: IBAP e APRODAB e ADCOAS, v. 27, set/out de 2004.

CINTRA, Antônio Carlos de Araújo; DINAMARCO, Cândido Rangel; GRINOVER, Ada Pellegrini. Teoria Geral do Processo. 18. ed. São Paulo: Malheiros, 2002. 
COOLEY, John W. A advocacia na mediação. Brasília: Editora Universidade de Brasília, 2001.

DELGADO, José. Constitucionalidade da mediação. Mediação: Um Projeto Inovador. Série Cadernos do CEJ/Conselho de Justiça Federal, Centro de Estudos Judiciários, Brasília: CEJ, v. 21, 2003.

DIAS, José Carlos de Mello. Mediador: Uma Experiência Profissional. Mediação: Um Projeto Inovador. Série Cadernos do CEJ/Conselho de Justiça Federal, Centro de Estudos Judiciários, Brasília: CEJ, v. 21, 2003.

LARANJEIRA, Nina Paula Ferreira; MOURÃO, Laís. Conflito Socioambiental no setor habitacional Grande Colorado, APA de Cafuringa, DF. In: THEODORO, Suzi Huff (Org.). Mediação de Conflitos Socioambientais, Rio de Janeiro: Editora Garamond Ltda, 2005.

LENZA, Vítor Barbosa. Cortes Arbitrais. Revista CEJ/Conselho de Justiça Federal, Centro de Estudos Judiciários, Brasília: CEJ, v.17, ano VI, abr./jun. de 2002.

LITTLE, Paul E. Os Conflitos Socioambientais: um Campo de Estudo e de Ação Política. In: BURSZTYN, Marcel (Org.). A Difícil Sustentabilidade, Rio de Janeiro: Editora Garamond Ltda, 2001.

MACHADO, Paulo Affonso Leme. Direito Ambiental Brasileiro. São Paulo: Malheiros Editores Ltda, 2003.

MANUAL DO MEDIADOR. Brasília: Ministério do Trabalho e Emprego, 2001.

MILARÉ, Edis. Direito do ambiente: doutrina, pratica, jurisprudência, glossario. São Paulo: Editora Revista dos Tribunais, 2001.

MINISTERIO DO MEIO AMBIENTE. Declaração do Rio de Janeiro. Disponível em: < http://www.mma.gov.br/index.php?ido=conteudo.monta\&idEstrutura=18\&idConteudo=576>. Acesso em: 10 nov. 2005.

MOORE, Christopher W. O Processo de Mediação: estratégias e práticas para a resolução de conflitos. Porto Alegre: Editora Artes Médicas Sul, 1998.

NASCIMENTO, Elimar Pinheiro. Os Conflitos na Sociedade Moderna: uma Introdução Conceitual. In: BURSZTYN, Marcel (Org.). A Difícil Sustentabilidade, Rio de Janeiro: Editora Garamond Ltda, 2001.

OLIVEIRA, Luiz Rodriguez de; BURSZTYN, Marcel. Conflitos Socioambientais nas reservas legais em bloco: O caso do PA Margarida Alves, em Rondônia. In: THEODORO, Suzi Huff (Org.). Mediação de Conflitos Socioambientais, Rio de Janeiro: Editora Garamond Ltda, 2005. 
OLIVEIRA, Regis Fernandes de. Mediação (Instrumento da Pacificação Social). Revista dos Tribunais. Brasília: Editora Revista dos Tribunais, v. 799, maio 2002, ano 91.

PROJETO JUSTIÇA COMUNITÁRIA. Brasília: [s.e], 2000.

RED MESOAMERICANA DE MANEJO DE CONFLICTOS SOCIOAMBIENTALES. Conflictos socio ambientales en América Latina: una visión desde la Red Mesoamericana de Manejo de Conflictos Socio Ambientales. Costa Rica: Universidad para la Paz, 1999.

REDE DE INSTITUIÇÕES CAPACITORAS EM GESTÃO DO DESENVOLVIMENTO. Curso de Extensão em Gestão de Conflitos Ambientais. Disponível em: $<$ http://www.ric.org.br/leia_mais.php?id=537_0_10_0_M38>. Acesso em: 10 nov. 2005.

RISKIN, Leonard L. Compreendendo as Orientações, Estratégias e Técnicas do Mediador: Um Padrão para Iniciantes. In: AZEVEDO, André Gomma de (org.). Estudos em arbitragem, mediação e negociação. Brasília: Brasília Jurídica, 2002.

ROCHA, Jefferson Marçal. As limitações da "ciência" diante da problemática ambiental: em busca de novos pressupostos. Disponível em: $<$ http://www.anppas.org.br/gt/teoria_meio_ambiente/Jefferson_\%20Mar\%E7al\%20da\%20Ro cha.pdf>. Acesso em: 10 maio. $200 \overline{6}$.

SALES, Lília Maia de Morais. Justiça e Mediação de Conflitos. Belo Horizonte: Del Rey, 2003.

SATO, Sandra. Ministra anuncia câmara de mediação de conflitos ambientais. Disponível em: < http://www.estadao.com.br/ciencia/noticias/2003/dez/19/187.htm>. Acesso em: 10 nov. 2005.

SERPA, Maria de Nazareth. Teoria e Prática da Mediação de Conflitos. Rio de Janeiro: Editora Lumen Juris, 1999.

SILVA, João Roberto da. A Mediação e o Processo de Mediação. São Paulo: Paulistanajur Ltda, 2004.

SILVA, José Afonso. Direito Constitucional Ambiental. São Paulo: Malheiros, 1997.

SIX, Jean-François. Dinâmica da mediação. Belo Horizonte: Del Rey, 2001.

SCHNITMAN, Dora Fried. Novos Paradigmas na Resolução de Disputas. In: SCHNITMAN, Dora Fried (Org.). Novos paradigmas em mediação. Porto Alegre: Artes Médicas Sul, 1999.

THEODORO, Suzi Huff. Uma crise anunciada. In: THEODORO, Suzi Huff (Org.). Mediação de Conflitos Socioambientais, Rio de Janeiro: Editora Garamond Ltda, 2005. 
THEODORO JÚNIOR, Humberto. Curso de Direito Processual Civil. Rio de Janeiro: Forense, 2001.

VEZZULlA, Juan Carlos. Teoria e Prática da Mediação. Curitiba: Instituto de Mediação e Arbitragem do Brasil, 1998.

WARAT, Luis Alberto. O ofício do mediador. Florianópolis: Habitus, 2001.

WATANABE, Kasuo. Modalidades de Mediação. Mediação: Um Projeto Inovador.Série Cadernos do CEJ/Conselho de Justiça Federal, Centro de Estudos Judiciários, Brasília: CEJ, v. 21, 2003. 


\begin{abstract}
ANEXO A
Anteprojeto de Lei sobre a Mediação no Processo Civil - Exposição de

Motivos
\end{abstract}

ADA PELLEGRINI GRINOVER coordenou a comissão que apresentou Anteprojeto de lei instituindo a mediação no processo civil, prestes a ser apresentado ao Congresso Nacional.

1. O avanço dos mecanismos extrajudiciais de solução de controvérsias é inegável no Brasil: a partir da vitoriosa experiência dos Juizados Informais de Conciliação, ficou clara a aspiração social por métodos que pudessem servir para a resolução dos conflitos sociais fora dos meandros do Poder Judiciário, cujos órgãos estão sabidamente sobrecarregados e cuja atuação dificilmente consegue a pacificação das partes.

2. O legislador não ficou insensível ao clamor social: procurou, de um lado, fortalecer a vertente extrajudicial de solução de controvérsias, o que se concretizou com a edição da Lei 9.307/96, que revitalizou a arbitragem; de outra parte, na vertente judicial, reforçou os poderes conciliatórios do juiz, estimulando sua atividade (mediadora) no curso do processo, como se viu com a edição da Lei 8.952/94 que alterou, entre outros, os artigos 125 e 331 do Código de Processo Civil.

3. Mas ainda não era o bastante. A conciliação judicial sofre uma série considerável de pressões adversas, de modo a tornar limitados seus resultados práticos: as pautas dos juízes estão lotadas, de tal sorte que estes não podem dedicar-se ao trabalho naturalmente lento da mediação; nem todos os magistrados são treinados (e muito menos vocacionados) para conciliar; as partes mostram-se sempre intimidadas na presença dos juízes, de modo que a inibição e o receio de avançar posições, que podem posteriormente desfavorecê-las no julgamento da causa, acabam por tornar difícil a composição dirigida pelo magistrado; os advogados cultivam mais a postura litigiosa do que a consensual; os magistrados sentem-se desconfortáveis quando, na atividade conciliatória, revelam seu entendimento acerca de determinadas questões, o que pode ser interpretado pelas partes como parcialidade ou até mesmo induzir ao pré-julgamento. Estas dificuldades já haviam sido notadas pelo legislador, que procurou mitigá-las quando editou a lei 7.244/84 (que implantou os Juizados Especiais de Pequenas Causas), valorizando o papel dos conciliadores. O sucesso da iniciativa foi notável, consolidando-se a posição dos conciliadores na lei 9.099/95, que hoje disciplina os Juizados Especiais Cíveis e Criminais.

4. Paralelamente, a iniciativa da mediação tomou impulso no Brasil. A criação de centros de arbitragem, impulsionados pela Lei 9.307/96, também ocasionou a abertura dessas instituições à mediação, que floresceu em todo o país, cultivada também por mediadores independentes. Embora próximas, por tenderem ambas à auto-composição (e apartando-se, assim, da arbitragem, que é um meio de hetero-composição de controvérsias, 
em que o juiz privado substitui o juiz togado), conciliação e mediação distinguem-se porque, na primeira, o conciliador, após ouvir os contendores, sugere a solução consensual do litígio, enquanto na segunda o mediador trabalha mais o conflito, fazendo com que os interessados descubram as suas causas, removam-nas e cheguem assim, por si só, à solução da controvérsia. Parece, entretanto, que a própria mediação apresenta duas facetas: sendo seus objetivos resolver o conflito e conseguir o acordo, a mediação clássica, que não se volta precipuamente ao processo, dá ênfase à solução do conflito, sendo o acordo apenas o seu apêndice natural, podendo vir, ou não; enquanto a mediação voltada ao processo dá ênfase sobretudo à obtenção do acordo, porque tem em vista o escopo precípuo de evitar ou encurtar o processo, sendo a pacificação dos contendores a conseqüência de um acordo alcançado pelo consenso dos interessados. Para indicar este segundo tipo de mediação, o Projeto de Lei, que dela se ocupa exclusivamente, denomina-a "paraprocessual" (para=ao lado de, elemento acessório ou subsidiário).

5. Observe-se, ainda, que na mediação paraprocessual, acima descrita, o mediador não deve permanecer exclusivamente no campo do esclarecimento das causas do conflito, evitando a formulação de uma proposta de acordo. Ao contrário, é conveniente que o mediador sugira aos contendores a solução, dando-lhe roupagem jurídica. Assim sendo, podese afirmar que, na mediação voltada ao processo, o mediador deverá ser ao mesmo tempo um conciliador.

6. O presente Projeto de Lei pretende institucionalizar a mediação extrajudicial voltada, ou trazida, ao processo civil, de modo a potencializar a possibilidade de resolução de controvérsias independentemente da intervenção do juiz estatal, o que tende a abrir mais espaço para a regularização dos serviços judiciários, com substancial diminuição do tempo de espera gerado pela sobrecarga de trabalho dos magistrados e, ao mesmo tempo, estimular a participação popular na administração da Justiça e pacificar os litigantes.

7. O projeto investe em duas modalidades de mediação: a primeira, denominada mediação prévia (que será sempre facultativa), permite ao litigante, antes mesmo de ajuizar demanda, procurar o auxílio de um mediador para resolver o conflito de interesses; a segunda, incidental (e cuja tentativa é obrigatória), terá lugar sempre que for distribuída demanda (excepcionadas as causas arroladas no Art. $5^{\circ}$ da lei) sem prévia tentativa de mediação, de sorte que, obtido o acordo, se extinguirá o processo sem a necessidade de intervenção do juiz estatal.

8. A tentativa obrigatória de mediação incidental não fere o disposto no Art.5 $5^{\circ}$, inciso XXXV, da Constituição Federal, que dispõe a respeito da inafastabilidade do acesso aos tribunais porque, diversamente do que ocorre com outros diplomas legislativos, ela ocorrerá após o ajuizamento da demanda, com o que se puderam conferir à distribuição desta e à intimação dos litigantes efeitos que, pelo Código de Processo Civil, são próprios da citação (arts. $6^{\circ}$ e $8^{\circ}, \S 1^{\circ}$, do Projeto); e ainda porque a parte interessada poderá solicitar a retomada do processo judicial, decorrido o prazo de 60 (sessenta dias) da data do início do procedimento de mediação $\left(\right.$ Art. $\left.9^{\circ}, \S 3^{\circ}\right)$.

9. Ainda com relação à tentativa obrigatória de mediação, vale outra observação: a facultatividade tem sido sublinhada como um dos princípios fundamentais da mediação. No entanto, também tem sido apontada a necessidade de se operar uma mudança de mentalidade, para que a via consensual seja mais cultivada do que a litigiosa, o que é um 
dado essencial para o êxito das vias conciliativas, que compreendem a mediação. Assentado que os chamados meios alternativos de solução das controvérsias, mais do que uma alternativa ao processo, configuram instrumentos complementares, mais idôneos do que o processo para a pacificação, é preciso estimular a sedimentação de uma cultura que permita seu vicejar. E, para tanto, a tentativa obrigatória parece constituir o único caminho, não se descartando que, no futuro, a mediação paraprocessual se torne facultativa.

10. Aliás, justamente para impulsionar esta mudança de cultura, é evidente que a mediação proposta pelo Projeto não prejudica as demais oportunidades de conciliação judicial estabelecidas em lei.

11. Pelo projeto ora apresentado, os mediadores serão preparados para o serviço que prestarão à sociedade: para tanto, a contribuição da Ordem dos Advogados do Brasil será inestimável, seja com relação à capacitação e seleção dos profissionais, como também no que diz respeito ao controle de sua atividade. Os interessados em atuar como mediadores serão advogados, com experiência profissional mínima de dois anos e deverão submeter-se a curso preparatório, ao término do qual estarão, se aprovados, sujeitos a regras procedimentais adequadas para auxiliar as partes na busca de uma solução consensual para seu litígio. O projeto prevê a dispensa do curso preparatório para os Conciliadores dos Juizados Especiais Cíveis e para os Conciliadores Judiciais previstos para o rito sumário (Art. $277, \S 1^{\circ}$, do CPC), que comprovem o efetivo desempenho da função por pelo menos dois anos.

12. Também a esse propósito, cabe um esclarecimento: na mediação tradicional os mediadores têm preparação multidisciplinar e são originários de diversos campos profissionais. Mas o que tem que se ter em mente é que o projeto trata da mediação extrajudicial trazida para o processo civil e para este voltada, sendo aconselhável que seja ela conduzida por um profissional do direito, especialmente treinado, para que os litigantes possam chegar a um acordo que se revista das indispensáveis formalidades jurídicas, uma vez que a transação constituirá, sempre, título executivo extrajudicial e poderá, a pedido das partes e uma vez homologada pelo juiz, ter eficácia de título executivo judicial. Por outro lado, cumpre notar que o projeto também cuida da co-mediação, a ser levada a cabo por um mediador advogado juntamente com um profissional de outras áreas, nos casos em que qualquer dos litigantes o requeira ou o mediador sorteado o entenda conveniente e, necessariamente, nas controvérsias atinentes ao Direito de Família.

13. Naturalmente a atividade de mediação não estará desligada do controle do Poder Judiciário: para tanto, o Tribunal de Justiça de cada Estado da Federação manterá registro dos mediadores, por categoria profissional, sendo certo que, verificada a atuação inadequada de qualquer deles, poderá o juiz estatal afastá-lo de sua atividade, mandando averiguar a conduta indesejável em regular processo administrativo. O controle pelo juiz é complementado pelo da Ordem dos Advogados do Brasil e dos outros órgãos oficiais profissionais.

14. A atividade do mediador não será gratuita. A remuneração do profissional que dedicar seu tempo à atividade prevista na lei está escalonada de conformidade com o valor da causa, tendo sido fixada em patamares módicos, para que não seja onerado o acesso à Justiça. Em caso de co-mediação, os honorários estão estabelecidos no valor de $50 \%$ para cada mediador. Em caso de insucesso da mediação, não haverá 
pagamento de honorários. Prevê-se, ainda, a dispensa de qualquer pagamento quando for concedido o benefício de gratuidade de que trata a lei 1.060/50, hipótese em que (enquanto não for promulgada lei local sobre a matéria) atuarão como mediadores os defensores públicos ou quem exerça suas atribuições, sem prejuízo de convênios com a Ordem dos Advogados do Brasil.

15. Em apertada síntese, o Projeto de Lei ora proposto - sem inibir outras modalidades de mediação extrajudicial vinculadas a órgãos institucionais ou realizadas através de mediadores independentes, que também poderão ser credenciados pela $\mathrm{OAB}$ para a mediação voltada ao processo civil - coloca-se na esteira dos meios complementares de solução de controvérsias, em harmonia com o plano inserido na proposta de governo lançada pelo Presidente Fernando Henrique Cardoso. Trata-se de mais um elemento para a democratização da Justiça, que servirá não só para desafogá-la, mas também para melhorar substancialmente a qualidade da solução dos conflitos, já que ninguém nega a excelência da pacificação social obtida mediante o consenso. 


\begin{abstract}
ANEXO B
Projeto de Lei $\mathbf{n}^{0}$, de $\mathbf{2 . 0 0 1}$

Institui e disciplina a mediação paraprocessual como mecanismo complementar de solução de conflitos no processo civil.

O CONGRESSO NACIONAL decreta:

\section{CAPÍTULO I}

MODALIDADES DE MEDIAÇÃO PARAPROCESSUAL
\end{abstract}

Art. $1^{\circ}$. A mediação paraprocessual é um mecanismo complementar e consensual de solução de controvérsias, que tem como objetivo pacificar conflitos e buscar o acordo, por meio da atuação do mediador.

$\S 1^{\circ}$. A mediação poderá ser prévia ou incidental.

$\S 2^{\circ}$. A transação, subscrita pelo mediador, pelos transatores e advogados, constitui título executivo extrajudicial.

$\S 3^{\circ}$. A pedido dos litigantes, a transação poderá ser homologada pelo juiz, caso em que terá eficácia de título executivo judicial.

\title{
CAPÍTULO II
}

\section{SEÇÃO I}

\section{DA MEDIAÇÃO PRÉVIA}

Art. $2^{\circ}$. A mediação prévia é sempre facultativa.

Art. $3^{\circ}$. O litigante poderá optar pela mediação prévia, devendo o requerimento ser instrumentalizado por meio de formulário padronizado, que será subscrito por ele e seu advogado.

$\S 1^{\circ}$. A procuração instruirá o requerimento, facultada a exibição de provas pré-constituídas no curso do procedimento da mediação. 
$\S 2^{\circ}$. O requerimento de mediação prévia será distribuído ao mediador e a ele imediatamente encaminhado.

$\S 3^{\circ}$. Recebido o requerimento, o mediador designará dia, hora e local onde realizará a sessão de mediação, providenciando a comunicação pessoal, facultada a utilização de todos os meios eficazes de cientificação.

$\S 4^{\circ}$. A comunicação ao requerido conterá, ainda, a advertência de que deverá comparecer à sessão acompanhado de advogado. Não tendo o requerido advogado constituído, o mediador solicitará à Ordem dos Advogados do Brasil a designação de dativo.

Art. $4^{\circ}$. Levada a efeito a mediação, o mediador tomará por termo a transação, se obtida, ou consignará sua impossibilidade.

Parágrafo único. Obtida ou frustrada a transação, o mediador devolverá ao distribuidor o requerimento, acompanhado do termo, para as devidas anotações.

\section{SEÇÃO II}

\section{DA MEDIAÇÃO INCIDENTAL}

Art. $5^{\circ}$. A tentativa de mediação incidental é obrigatória no processo de conhecimento, salvo nos seguintes casos:

I - nas ações de estado;

II - na ação de interdição;

III - quando for autor ou réu pessoa incapaz;

IV - quando for autora ou ré pessoa de direito público;

V - na falência, na concordata e na insolvência civil;

VI - no inventário e no arrolamento, quando houver incapazes;

VII - nas ações de imissão de posse, reivindicatória de bem imóvel e de usucapião de bem imóvel;

VIII - na ação de retificação de registro público;

arbitragem;

IX - quando o autor optar pelo procedimento do juizado especial ou pela 
X - na ação cautelar;

XI - nas demais ações em que haja deferimento de liminar; e

XII - quando a mediação prévia, realizada na forma da Seção anterior, tiver ocorrido, sem resultado, nos 180 (cento e oitenta) dias anteriores ao ajuizamento da ação.

Art. $6^{\circ}$. Nos casos de mediação incidental, a distribuição da petição inicial ao juízo e ao mediador interromperá a prescrição, induzirá litispendência e produzirá os efeitos previstos no artigo 593 de Código de Processo Civil.

$\S 1^{\circ}$. Na hipótese de pedido de liminar, o processo será distribuído ao juiz para decisão, retomando o procedimento de mediação seu curso caso a medida seja indeferida.

$\S 2^{\circ}$. A interposição de agravo contra o indeferimento da liminar não prejudica o procedimento de mediação.

Art. $7^{\circ}$. A petição inicial será imediatamente remetida pelo distribuidor ao mediador sorteado, necessariamente advogado.

Art. $8^{\circ}$. Cabe ao mediador intimar os litigantes, por qualquer meio eficaz de comunicação, designando dia, hora e local para seu comparecimento, acompanhados dos respectivos advogados.

$\S 1^{\text {o }}$. A intimação constituirá o litigante em mora, tornando a coisa litigiosa.

$\S 2^{\circ}$. Não sendo encontrado o requerido, ou não comparecendo qualquer das partes, estará frustrada a mediação.

$\S 3^{\circ}$. Comparecendo o requerido sem advogado, o mediador procederá de acordo com o disposto na parte final do parágrafo $4^{\circ}$ do artigo $3^{\circ}$.

artigo $4^{\circ}$, caput.

Art. $9^{\circ}$. Levada a efeito a mediação, o mediador procederá nos termos do

$\S 1^{\circ}$. Obtida a transação, o mediador devolverá ao distribuidor a petição inicial, acompanhada do termo, para as devidas anotações.

$\S 2^{\circ}$. Frustrada a transação, o mediador remeterá a petição inicial ao juiz, acompanhada do termo, para a retomada do processo judicial.

$\S 3^{\circ}$. Decorridos 60 (sessenta) dias da data do início da mediação sem que tenha sido encerrado o respectivo procedimento, com a obtenção ou não da transação, poderá o interessado solicitar a retomada do processo judicial. 


\section{DOS MEDIADORES}

Art. 10. Os mediadores são auxiliares da Justiça, selecionados entre advogados, com pelo menos 2 (dois) anos de experiência.

$\S 1^{\circ}$. Caberá à Ordem dos Advogados do Brasil a formação e seleção de mediadores, para o que será implantado curso apropriado, fixando a Ordem dos Advogados do Brasil os critérios de aprovação, com a publicação do regulamento respectivo.

$\S 2^{\circ}$. Ficam dispensados do curso de capacitação os conciliadores dos Juizados Especiais Cíveis e os conciliadores judiciais a que se refere o art. $277, \S 1^{\mathrm{o}}$, do Código de Processo Civil, desde que comprovado o efetivo exercício da função por no mínimo 2 (dois) anos.

Art. 11. A pedido de qualquer dos litigantes, ou a critério do mediador, este trabalhará em regime de co-mediação, com profissional de outra área, devidamente habilitado, nos termos do $\S 2^{\circ}$ deste artigo.

$\S 1^{\circ}$. A co-mediação será obrigatória nas controvérsias que versem sobre Direito de Família, devendo dela sempre participar o mediador advogado.

$\S 2^{\circ}$. A Ordem dos Advogados do Brasil selecionará, como co-mediadores, profissionais indicados por organismos institucionais de mediação, devidamente credenciados, ou por órgãos profissionais oficiais.

$\S 3^{\circ}$. Quando no exercício de suas funções, e em razão delas, ficam os mediadores equiparados aos funcionários públicos para efeito da legislação penal.

Art. 12. O Tribunal de Justiça de cada Estado manterá um Registro de Mediadores, contendo o cadastro atualizado de todos os mediadores habilitados a atuar no âmbito do Estado, por área profissional.

$\S 1^{\mathrm{o}}$. Aprovado no curso de formação e seleção, ou dele dispensado (Art. 10, $\S 2^{\circ}$ ), o mediador, com o certificado respectivo, requererá inscrição no Registro de Mediadores no Tribunal de Justiça local, podendo atuar nos limites da comarca onde mantenha escritório ou, na falta deste, nos limites da comarca onde resida.

$\S 2^{\circ}$. Efetivado o registro, caberá ao Tribunal de Justiça remeter ao Diretor do Forum da comarca onde atuará o mediador os dados necessários para que o nome deste passe a constar do rol da Comarca, para efeito de distribuição (Art. $3^{\circ}, \S 2^{\circ}$, e art. $7^{\circ}$ ).

$\S 3^{\circ}$. Do Registro de Mediadores constarão todos os dados relevantes referentes à atuação do mediador, tais como o número de causas em que atuou, o sucesso ou insucesso de sua intervenção, a matéria sobre a qual versava a controvérsia, bem assim quaisquer outros dados que o Tribunal de Justiça local julgar relevantes. 
$\S 4^{\circ}$. Os dados colhidos na forma do parágrafo anterior serão classificados sistematicamente pelo Tribunal de Justiça que os publicará, pelo menos anualmente, para conhecimento da população e efeitos estatísticos, bem assim para o fim de avaliação da mediação e dos mediadores.

Art. 13. A mediação será sempre realizada em local de fácil acesso, com estrutura suficiente para atendimento dos litigantes de modo condigno.

$\S 1^{\circ}$. A Ordem dos Advogados do Brasil fixará, no prazo máximo de 60 (sessenta) dias após a promulgação desta Lei, as condições mínimas a que se refere este artigo.

$\S 2^{\circ}$. A mediação será realizada em local que preencha as condições fixadas pela Ordem dos Advogados do Brasil nos termos do parágrafo anterior, disponibilizado por entidade pública ou particular para o desenvolvimento das atividades de que trata esta Lei.

Art. 14. A fiscalização das atividades dos mediadores competirá à Ordem dos Advogados do Brasil, através de suas secções e subsecções, e ao juiz.

$\S 1^{\circ}$. Verificando o órgão fiscalizador irregularidade na prestação dos serviços pelo mediador, suspenderá imediatamente a autorização concedida, até apuração dos fatos, informando o Tribunal de Justiça acerca da providência para anotação no Registro de Mediadores.

$\S 2^{\circ}$. O magistrado, verificando atuação inadequada do mediador, poderá afastá-lo de suas atividades no processo, informando a Ordem dos Advogados do Brasil ou, em se tratando de profissional de outra área, o órgão competente, para instauração do respectivo processo administrativo.

$\S 3^{\circ}$. O processo administrativo para averiguação de conduta inadequada do mediador advogado, instaurado de ofício ou mediante representação, seguirá o procedimento previsto no Título III da Lei 8.906/94, podendo a Ordem dos Advogados do Brasil aplicar desde a pena de advertência até a de exclusão do Registro de Mediadores, tudo sem prejuízo de, verificada também infração ética, promover a entidade de classe as medidas de que trata a referida Lei.

Art. 15. Será excluído do Registro de Mediadores aquele que:

justificação;

I - assim o solicitar ao Tribunal de Justiça, independentemente de

II - agir com dolo ou culpa na condução da mediação sob sua responsabilidade;

III - violar os princípios de confidencialidade e neutralidade;

IV - funcionar em procedimento de mediação mesmo sendo impedido; 
V - violar o disposto no art. 17.

$\S 1^{\circ}$. Os casos previstos nos incisos II a IV serão apurados em regular processo administrativo, nos termos do art. 14 desta Lei.

$\S 2^{\circ}$. Nos casos dos incisos II a V o mediador excluído não será reinscrito no Registro de Mediadores, sendo a proibição extensiva a todo o território nacional.

Art. 16. Não será admitida a atuação do mediador nos termos do artigo 134 do Código de Processo Civil.

Parágrafo único. No caso de impedimento, o mediador devolverá os autos ao distribuidor, que sorteará novo mediador; se a causa de impedimento for apurada quando já iniciado o procedimento de mediação, o mediador interromperá sua atividade, lavrando ata com o relatório do ocorrido e solicitará sorteio de novo mediador.

Art. 17. No caso de impossibilidade temporária do exercício da função, o mediador informará o fato ao Tribunal de Justiça para que, durante o período em que perdurar a impossibilidade, não haja novas distribuições.

Art. 18. O mediador advogado fica impedido, pelo prazo de 1 (um) ano, contado a partir do término da mediação, de assessorar, representar ou patrocinar qualquer dos litigantes.

Art. 19. O mediador fará jus, pelos serviços prestados, a honorários, fixados segundo o valor atribuído à causa, na forma seguinte:

I - causas de valor até 40 salários mínimos, meio salário mínimo;

II - causas acima de 40 até 100 salários mínimos, 1 salário mínimo;

III - causas acima de 100 até 200 salários mínimos, 2 salários mínimos;

IV - causas acima de 200 até 500 salários mínimos, 4 salários mínimos;

V - causas cima de 500 até 1.500 salários mínimos, 6 salários mínimos;

VI - causas de valor superior a 1.500 salários mínimos, 6 salários mínimos, acrescidos de 1 a cada 100 salários mínimos, até o valor máximo de 20 salários mínimos.

$\S 1^{\circ}$. O litigante, ao requerer a mediação (Art. $3^{\circ}$ ) ou ao distribuir a petição inicial (Art. $6^{\circ}$ ), deverá efetuar por guia própria o depósito do valor dos honorários do mediador, cujo levantamento será efetuado na forma estabelecida pelo Tribunal de Justiça.

transação.

$\S 2^{\circ}$. O mediador somente fará jus aos honorários no caso de ser obtida a 
$\S 3^{\circ}$. Em caso de co-mediação, cada um dos mediadores fará jus a $50 \%$ (cincoenta por cento) da remuneração fixada neste artigo.

Art. 20. Nas hipóteses em que for concedido o benefício de gratuidade (Lei 1.060/50) estará o litigante dispensado do recolhimento dos honorários do mediador.

$\S 1^{\circ}$. Havendo pedido de concessão do benefício de gratuidade, o distribuidor remeterá os autos ao juiz competente para decisão.

$\S 2^{\circ}$. Enquanto não for promulgada lei local sobre a matéria, atuarão como mediadores os defensores públicos ou quem exerça suas atribuições, devidamente capacitados nos termos do art. 10, $\S 1^{\circ}$, sem prejuízo de convênios com a Ordem dos Advogados do Brasil.

Art. 21. As disposições desta Lei não excluem outras formas de mediação extrajudicial vinculadas a órgãos institucionais ou realizadas através de mediadores independentes.

Art. 22. Esta Lei entrará em vigor no prazo de cento e oitenta dias da data de sua publicação, exceto o $\S 1^{\circ}$ do art. 10 , que entrará em vigor no prazo de sessenta dias após a data da publicação da Lei. 